\title{
The Role of Ubiquitin-Protein Ligases in Neurodegenerative Disease
}

\author{
Helen C. Ardley Philip A. Robinson \\ Molecular Medicine Unit, University of Leeds, St. James's University Hospital, Leeds, UK
}

\section{Key Words}

Ubiquitylation - Ubiquitin-protein ligase .

Skp1-Cdc53/cullin-F-box complexes · RING domain . HECT domain · Neurodegeneration • Inclusions • Aggresomes

\begin{abstract}
Alzheimer's disease and Parkinson's disease are the most common neurodegenerative conditions associated with the ageing process. The pathology of these and other neurodegenerative disorders, including polyglutamine diseases, is characterised by the presence of inclusion bodies in brain tissue of affected patients. In general, these inclusion bodies consist of insoluble, unfolded proteins that are commonly tagged with the small protein, ubiquitin. Covalent tagging of proteins with chains of ubiquitin generally targets them for degradation. Indeed, the ubiquitin/proteasome system (UPS) is the major route through which intracellular proteolysis is regulated. This strongly implicates the UPS in these diseaseassociated inclusions, either due to malfunction (of specific UPS components) or overload of the system (due to aggregation of unfolded/mutant proteins), resulting in subsequent cellular toxicity. Protein targeting for degradation is a highly regulated process. It relies on transfer of ubiquitin molecules to the target protein via an enzyme cascade and specific recognition of a substrate pro-
\end{abstract}

\section{KARGER}

Fax +41613061234

E-Mail karger@karger.ch

www. karger.com
(C) 2004 S. Karger AG, Basel

1660-2854/04/0013-0071\$21.00/0

Accessible online at:

www. karger.com/ndd tein by ubiquitin-protein ligases (E3s). Recent advances in our knowledge gained from the Human Genome Mapping Project have revealed the presence of potentially hundreds of E3s within the human genome. The discovery that parkin, mutations in which are found in at least $50 \%$ of patients with autosomal recessive juvenile parkinsonism, is an E3 further highlights the importance of the UPS in neurological disease. To date, parkin is the only E3 confirmed to have a direct causal role in neurodegenerative disorders. However, a number of other (putative) E3s have now been identified that may cause disease directly or interact with neurological disease-associated proteins. Many of these are either lost or mutated in a given disease or fail to process disease-associated mutant proteins correctly. In this review, we will discuss the role(s) of E3s in neurodegenerative disorders.

Copyright $@ 2004$ S. Karger AG, Basel

\section{Introduction}

Neurodegenerative disorders such as Alzheimer's (AD), Parkinson's (PD) and Huntington's (HD) disease and prion disorders are characterised by a selective and symmetric loss of neurons in specific regions of the brain. The result is disruption to motor, sensory or cognitive systems, causing such severe disability that premature death of a sufferer is an inevitable consequence. The majority of 
these diseases affect patients later in life. There is currently no cure or long-term treatment for these progressive diseases. Even where there are therapies, such as the administration of levodopa or other dopamine agonists in PD, these are often only effective in the short term. Consequently, given that in the UK the number of people over 60 years old will soon exceed those under 16 years old [1], it is essential that we elucidate the fundamental processes underlying theses disorders in order to develop novel therapeutic agents to help an ageing population.

The cause(s) of sporadic neurodegenerative disease remain(s) elusive. A complex mixture of underlying genetic polymorphisms, possibly in genes associated with hereditary forms of the disease, and/or exposure to environmental stresses may make an individual particularly vulnerable.

The pathological hallmark of many neurodegenerative diseases is the presence of ubiquitin-positive, intra- or extracellular inclusion bodies in affected regions of the brain [2-4]. However, it remains uncertain whether the toxicity associated with their presence or formation is the result of the presence of the inclusion body per se or a loss of normal protein function that results from its sequestration into an inclusion. Moreover, inclusions may occur as a result of attempts by neurons to protect themselves from toxic proteins. Inclusion models have been developed both in mice and cell culture systems, which recapture many of the properties of these endogenous inclusions [515]. These are generally based upon the (over-)expression of (mutated) core proteins associated with these inclusions that are also found in rare inherited cases of the diseases, such as $\beta$-amyloid $(\mathrm{A} \beta)$ in $\mathrm{AD}$ or $\alpha$-synuclein in PD.

In general, these inclusions consist of insoluble, unfolded, ubiquitylated polypeptides that fail to be degraded by the $26 \mathrm{~S}$ proteasome. Their apparent stability may, in part, be due to decreased levels of $26 \mathrm{~S}$ proteasomal activity, which is associated with increasing age [16]. Given the pathological presentation of these conditions, it is perhaps not surprising that an increasing number of proteins associated with the ubiquitin-proteasome system (UPS) are now known to play either a direct or indirect role in familial forms of disease [for recent reviews, see ref. 17-21].

Ubiquitin-protein ligases (E3s) are of particular importance as they determine the targeting specificity of the ubiquitin system. Such molecules have been found to be mutated, absent or malfunction in some hereditary forms of neurodegenerative disorders. These include parkin, dorfin and the recently identified malin. Of all the proteins discussed herein, to date, parkin (and possibly
$\mathrm{UCH}-\mathrm{L} 1)$ is the only one confirmed to have both E3 activity and a direct causal role in neurodegenerative disease. However, a number of others, in particular malin, mutations in which are associated with Lafora disease, are likely to play either direct, or indirect, roles in the aetiology of their associated disorders. The focus of this review will be E3s that may have a functional role in human neurodegenerative disorders.

\section{Aberrant Protein Accumulation: Refold or Degrade?}

Regulating the level of a functionally active protein is a highly complex and tightly regulated process. A fine balance between its rate of synthesis and degradation, which may be dependent on post-translational modification, must be maintained. Additional complicating factors may include the availability of one or more interacting proteins and its intracellular location. Normally, newly synthesised polypeptides emerge from the ribosome to be met by molecular chaperones that ensure their appropriate folding and intracellular localisation, whilst preventing their aggregation [22, 23]. Misfolded 'escapees' are rapidly targeted for degradation via the UPS [24].

UPS-mediated post-translational modification and degradation of proteins is essential for many fundamental cellular functions that include cell cycling, DNA repair, cell signalling, gene transcription and apoptosis. Indeed, the UPS is now recognised to be the major route by which proteins are specifically selected for spatiotemperal degradation in eukaryotic cells [for recent reviews, see ref. 2530].

The covalent attachment of the 76-amino acid residue protein, ubiquitin, to an $\varepsilon$-amino group of a lysine residue in a target protein involves an energy-dependent, fourstep pathway (fig. 1). Ubiquitin is transferred from an ubiquitin-activating enzyme (E1), to an ubiquitin-conjugating enzyme (E2) and then to the target protein. This latter step is facilitated by an E3. Multiple rounds of ubiquitylation via attachment of additional ubiquitin moieties (generally through ubiquitin Lys48) may then occur leading to the generation of polyubiquitin chains. These polyubiquitylated conjugates (at least 4 ubiquitin molecules must be attached) are then selected for degradation by the $26 \mathrm{~S}$ proteasome. During this process, ubiquitin is removed and the target protein degraded into small peptides. These latter molecules can be hydrolysed further by other cellular peptidases or used for antigen presentation $[31,32]$. 
The requirement for the addition of multiple ubiquitin molecules may be part of a proof-reading mechanism, as a large number of de-ubiquitinating enzymes (DUBs) are also found within cells [33-35]. This latter group of enzymes may remove ubiquitin moieties before a sufficiently long ubiquitin chain has been synthesized to activate proteasomal destruction. Alternatively, they may also prevent the synthesis of chains of such a length that they promote unwanted aggregation of proteins.

More recently, monoubiquitylation of proteins has been demonstrated to have major functional roles that are apparently independent of degradation, in particular, regulation of endocytosis of cell surface receptors, DNA repair mechanisms and transcription regulation [for a recent review, see ref. 36].

\section{E3s: Enzymes and Scaffolds}

The selectivity of the UPS essentially lies in the specificity of interaction between an E3 and a target protein. In some cases, the need for substrate post-translational modification such as phosphorylation permits an E3 to selectively target more than one substrate within a given cell $[37,38]$. Hence, the initial trigger for substrate selection will be independent of the ligase but be dependent on the activity of a kinase.

Two major classes of E3 have been identified. These are members of the E6-AP-related family of 'HECT' (homologous to the E6-AP C terminus) domain E3s [39] and the potentially much larger 'RING (really interesting new gene) finger domain' types [40-42]. These latter types of E3s do not appear to have a direct catalytic role in protein ubiquitylation but act as scaffolds or 'facilitators of interaction'. By contrast, HECT domain family members directly catalyse the final attachment of ubiquitin to substrate proteins through their approximately 350 amino acid C-terminal HECT domains [39].

One of the first E3s to be identified and characterised was E6-AP1 (E6-associated protein 1) [43]. Subsequently, many other proteins characterised by the HECT domain have been identified [39, 44-47]. HECT type E3s function in a similar manner to E1 and E2s containing a defining Cys residue in the HECT domain. The thiol group of the Cys residue forms a thioester bond with the carboxy group of the glycine residues found at the $\mathrm{C}$ terminus of ubiquitin prior to its transfer to the target protein.

However, E3s characterised by a RING finger domain are likely to represent the largest group of ligases. In fact, the RING domain is the fourth most common protein motif in the human genome, indicating that although unlikely that all of these will display E3 activity, many

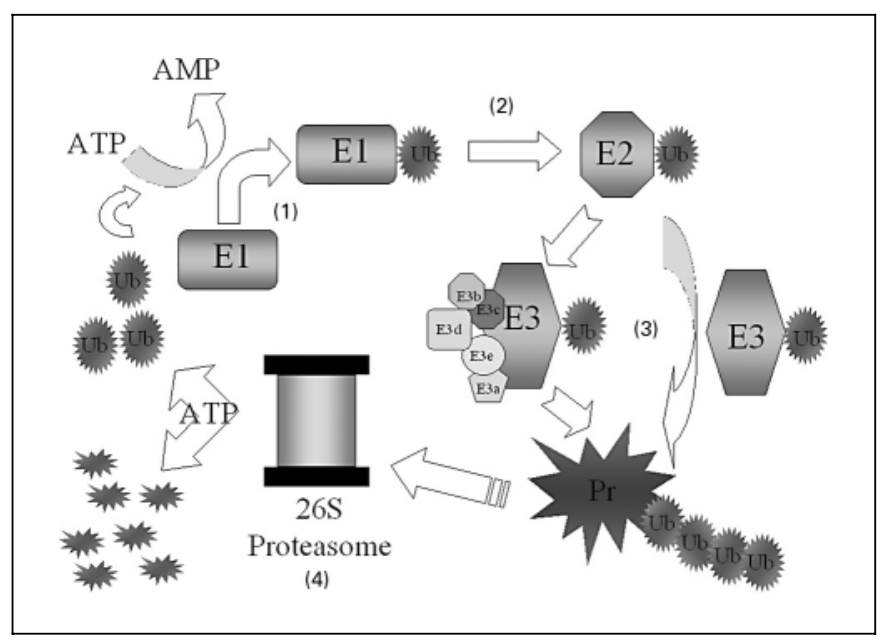

Fig. 1. Protein-mediated degradation via the ubiquitin-proteasome pathway. Ubiquitylation occurs in a step-wise manner. (1) Energydependent thioester bond formation between the C-terminal glycine residue of ubiquitin $(\mathrm{Ub})$ and a thiol group located within an ubiquitin-activating enzyme (E1). (2) Ubiquitin is then transferred to an ubiquitin-conjugating enzyme (E2) via transthiolation. (3) E3s then facilitate ubiquitylation of the target protein (Pr). E3s may be large multi-subunit complexes (left-hand side) or single proteins (righthand side). Multiple ubiquitin molecules may then be covalently attached to one of several lysine residues found within a pre-attached ubiquitin to form a polyubiquitylated protein. (4) Chains of at least 4 ubiquitin molecules are required for recognition by the $26 \mathrm{~S}$ proteasome. Polyubiquitylated proteins not selected for immediate $26 \mathrm{~S}$ proteasomal-mediated, ATP-dependent, degradation may be deubiquitylated by one of many DUBs found within cells.

more E3s of this type are yet to be elucidated [48]. These E3s are involved in regulating diverse cellular functions including roles in apoptosis, cell cycle control and tumour suppressor function $[49,50]$. They can act either alone [50-54] or as a component of a multiprotein E3 ligase complex such as an Skp1-Cdc53/cullin-F-box (SCF) complex $[55,56]$, the anaphase-promoting complex $[57,58]$ or the von Hippel-Lindau tumour suppressor protein complex $[59,60]$.

The RING finger domain is a Cys/His-rich, zinc-chelating domain that promotes both protein to protein and protein to DNA interactions [61]. It appears that the RING structure is essential for the E2:E3 interaction and, consequently, the E3 activity of the protein [50-54]. Importantly, although many proteins characterised by a RING finger motif possess $\mathrm{E} 3$ activity in vitro, there is no evidence to suggest that all RING finger proteins behave as E3s under normal physiological conditions. Indeed, the promyelocytic leukemia tumour suppressor protein, 
which is a RING protein, inhibits mRNA translation by initiation factor eIF4E by mechanisms that do not involve the UPS [62].

Recently, a putative third class of E3s has been identified and characterised, the U-box ligases [63-65]. These proteins appear to act in a similar manner to RING finger proteins. However, they lack the characteristic Cys and His residues that define the RING finger domain structure. Nevertheless, due to their structural similarity to the RING motif, they may also be classified as a subclass of RING finger type E3s [66].

Of note, many HECT and RING finger domain E3s 'autoubiquitylate' in in vitro and in eukaryotic cell overexpression systems [67-69]. Although this may simply be an in vitro artefact brought about by high levels of expression of a given protein, autoubiquitylation may represent a gain-of-function and protective cellular mechanism, by which certain types of proteins including RING finger proteins are programmed to self-destruct to prevent their aggregation when overexpressed. The latter proposal may be particularly relevant in neurological disorders associated with ageing where reduced proteasomal activity may cause increased levels of E3 autoubiquitylation as well as stabilisation of substrate proteins.

\section{Pathological Inclusions and Aggresomes}

The pathological hallmark of many neurodegenerative diseases is the presence of insoluble intra- or extracellular inclusion bodies in affected regions of the brain. The major constituents of these inclusions are misfolded proteins. Their aggregation into proteinaceous inclusions is perhaps surprising given that there are cellular processes present designed to prevent such events. Moreover, what is also puzzling is the observation that these inclusions are found almost exclusively within certain subgroups of neurons in specific regions of the brain regardless of the widespread tissue distribution of the core proteins.

The classic causes for protein misfolding, which lead to a loss of function, are missense mutations, protein modifications or post-translational damage, or expansion of amino acid repeats as is observed in polyglutamine disorders. Misfolded proteins may be 'rescued' via chaperones and co-chaperones as has been observed for ataxin-1, parkinassociated endothelin-receptor-like receptor (Pael-R) and $\alpha$-synuclein [70-72]. However, should these chaperonemediated pathways or the UPS fail, misfolded proteins that are prone to aggregation may form insoluble inclusions (fig. 2). These inclusion bodies are usually characterised by the presence of aggregates of one major 'core' protein, or peptide, and a series of other associated proteins.
The latter components often include chaperones such as Hsp70, Hsp27 and $\alpha B$-crystallin [73-76]; UPS components including parkin, proteasomal subunits and ubiquitin [2, 77-79], and cytoskeletal elements such as tau, tubulin-associated proteins and neurofilaments [80-83].

Overexpression of a number of neurodegenerative disease-associated proteins including presenilin 1 (PS1), parkin and huntingtin (associated with $\mathrm{AD}, \mathrm{PD}$ and $\mathrm{HD}$, respectively) in proteasome-inhibited mammalian cells leads to inclusion formation [5, 10, 12, 15]. Moreover, disease-associated mutant proteins readily form aggregates without the need for proteasome inhibition $[10,15$, $84,85]$. These inclusions have been characterised as 'aggresomes' [5, 10, 86-88]. It is postulated that endogenous aggresomes occur when increased levels of substrate expression exceed the capacity of the proteasome. Indeed, McNaught et al. [76] have recently reported that the proteinaceous pathological hallmark of PD, the Lewy body, may represent a specialised aggresome-related inclusion specific to dopaminergic neurons.

\section{UPS in Neurodevelopment and Neurodegeneration}

Although the aim of this review was to focus on the role of E3s in neurodegeneration, the functions of the UPS in neurological conditions is by no means restricted to problems of later life. Indeed the function of several UPS components has been implicated in normal eukaryotic neurodevelopment. A mutation in the Drosophila Bendless gene, which encodes an E2, impairs axonal guidance [89, 90]. Null mutants of Ariadne-1, a Drosophila RING finger domain E3, result in embryonic lethality at the pupal stage, with occasional adult survivors displaying severe disruption of the central nervous system [91]. Furthermore, targeted neuronal overexpression of Fat facets, a DUB, results in abnormal synaptogenesis and impaired synaptic function in Drosophila [92]. In humans, loss of activity of the imprinted gene coding for the HECT E3, E6-AP1, leads to Angelman syndrome, a condition associated with severe motor and intellectual retardation and ataxia $[93,94]$.

\section{E3s in Neurodegenerative Disorders}

There has been a rapid explosion in our knowledge of the UPS and its many cellular functions over the last 5 years. One of the major discoveries was the characterisa- 
Fig. 2. Inclusion bodies are a common occurrence in most neurodegenerative diseases. a Correct folding of newly synthesised proteins is mediated by the chaperone system to produce functionally active proteins (post-translational modifications may also be required). Misfolded proteins are either unfolded and refolded by chaperones or targeted to the UPS for degradation. b In many inherited neurodegenerative conditions, most of the newly synthesised mutant protein (mutation shown as a grey sphere) may be rapidly targeted to the UPS via ubiquitylation. However, some may be correctly folded, with few displaying functional activity. Ubiquitylated, misfolded mutant proteins and/or poorly ubiquitylated folded protein may not be easily recognised by the proteasome causing a build-up of ubiquitylated species. These 'pre-inclusions' may be highly toxic to the cell and cause rapid cell death. Protein aggregates that reach the proteasome may cause blockage of the degradation machinery preventing proteolysis of other UPS targets, causing greater accumulation of proteins and aggresome formation. These inclusions will eventually cause severe impairment of proteasome activity resulting in increased cellular toxicity and eventual cell death. In sporadic disease, a slowing down of proteasomal activity with age may lead to an increase in aggregated proteins causing inclusion formation. In either scenario, exposure to additional environmental stresses may make a cell more susceptible to inclusion formation. a

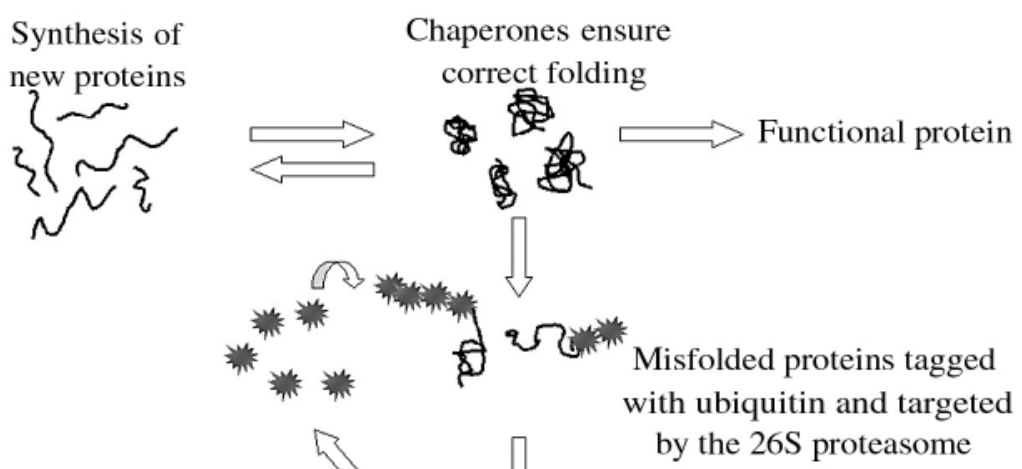

Recycling of ubiquitin

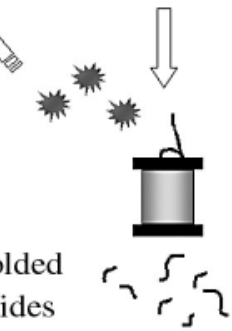

b

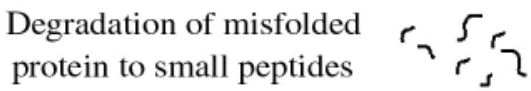

by the $26 \mathrm{~S}$ proteasome

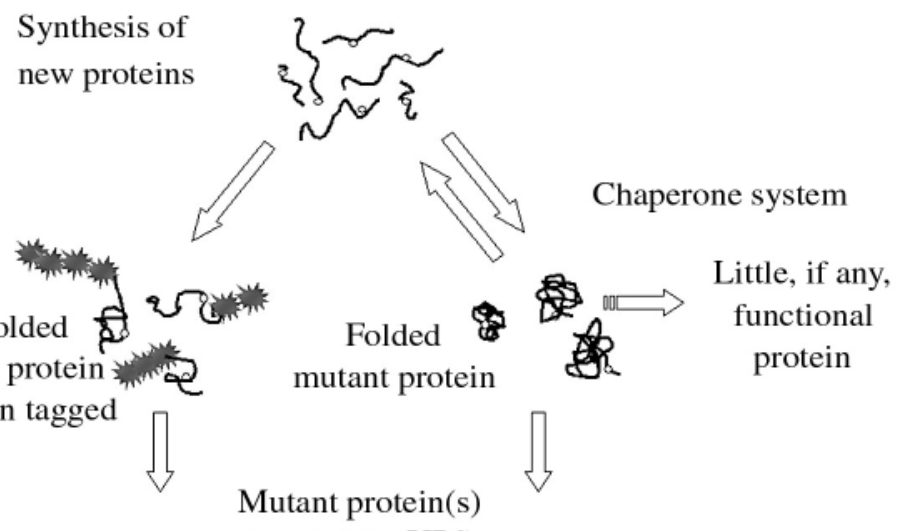

targeted by UPS

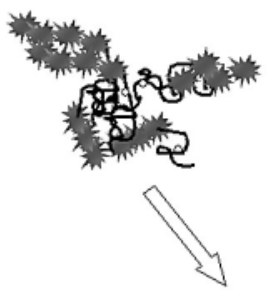

Blockage of 26S proteasome
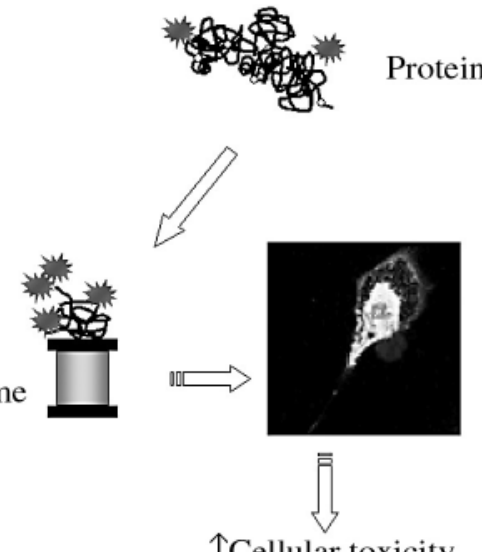

Protein aggregates

mutant protein ubiquitin tagged

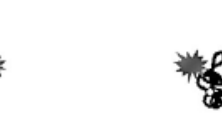

Inclusion

formation

个Cellular toxicity

$=$ CELL DEATH 
Table 1. E3s associated with neurodegenerative disorders

\begin{tabular}{|c|c|c|}
\hline Disease & $\begin{array}{l}\text { E3(s) implicated } \\
\text { in disease }\end{array}$ & Type of E3 \\
\hline Alzheimer's disease & $\begin{array}{l}\mathrm{SCF}{ }^{\mathrm{hCdc} 4} \\
\mathrm{TRIM} 11\end{array}$ & $\begin{array}{l}\text { multicomponent } \\
\text { RING }\end{array}$ \\
\hline Parkinson's disease & $\begin{array}{l}\text { parkin }^{1} \\
\text { CHIP } \\
\text { UCH-L1 }{ }^{1} \\
\text { dorfin }\end{array}$ & $\begin{array}{l}\text { RIR } \\
\text { U-box } \\
\text { novel, requires } \\
\text { dimerisation } \\
\text { RIR }\end{array}$ \\
\hline Amyotrophic lateral sclerosis & dorfin & RIR \\
\hline Huntington's disease & $\begin{array}{l}\text { RNF2 } \\
\text { RNF24 } \\
\text { HIPI-8 } \\
\text { HSD-4 }\end{array}$ & $\begin{array}{l}\text { RING } \\
\text { RING } \\
\text { RING } \\
\text { RING }\end{array}$ \\
\hline $\begin{array}{l}\text { Spinobulbar muscular } \\
\text { atrophy }\end{array}$ & $\begin{array}{l}\text { SNURF/RNF4 } \\
\text { ARA54 } \\
\text { ARNIP }\end{array}$ & $\begin{array}{l}\text { RING } \\
\text { RIR } \\
\text { RING }\end{array}$ \\
\hline Ataxia, SCA1 & E6-AP & HECT \\
\hline $\begin{array}{l}\text { Dentatorubral-pallidoluysian } \\
\text { atrophy }\end{array}$ & $\begin{array}{l}\text { AIP2 } \\
\text { AIP4/ITCH } \\
\text { AIP5 }\end{array}$ & $\begin{array}{l}\text { HECT } \\
\text { HECT } \\
\text { HECT }\end{array}$ \\
\hline Prion diseases & mahogunin & RING \\
\hline Lafora disease & malin $^{1}$ & RING \\
\hline
\end{tabular}

E3s which have been either directly linked to a neurodegenerative disease or are known to interact with disease-associated proteins.

1 Mutations/deletions in the genes encoding these proteins have been directly linked to some familial forms of disease.

tion of the RING finger as a (multi-)protein domain capable of E3 activity. Subsequently, hundreds of proteins have been identified within the protein databases that may have ligase activity. Many of these proteins, and those of the E3 family containing an HECT domain, are now being identified as proteins that are either directly responsible for, or associated with specific neurodegenerative disorders (table 1). Our current understanding of the role of the E3 in major neurodegenerative disease is summarised below.

\section{Alzheimers' Disease}

Dr. Alois Alzheimer first described AD nearly a century ago in 1906 . Despite its high incidence rate $(5-10 \%$ of the population over 65 years are affected, with a preva- lence rate increasing to $50 \%$ of those over 85 years), and much research, inadequate understanding of the condition means there is still no curative treatment or prevention strategy available. AD affects the central nervous system resulting in loss of memory, declining cognitive function and ultimately decreased physical function. The disease is characterised by the accumulation of extracellular amyloid plaques and cytoplasmic paired helical filaments made up of neurofibrillary tangles $[95,96]$. The main constituent of the former is a product $(\mathrm{A} \beta)$ of the processing of the amyloid precursor protein (APP), whereas that of the latter are phosphorylated forms of the microtubule-associated protein, tau. Both types of inclusion are ubiquitin positive [2,97].

Up to $10 \%$ of $\mathrm{AD}$ cases are due to inherited forms of the disease. To date, 3 genetic loci have been associated with familial AD: APP on chromosome 21, PS1 on chromosome 14 and presenilin 2 (PS2) on chromosome 1 [98100]. All 3 mutant genes can increase $A \beta$ deposits and subsequent plaque formation. PS1 and PS2 are likely to be components of the multi-protein $\gamma$-secretases required for proteolytic cleavage of APP to form $A \beta[101,102]$. Presenilins are degraded via the UPS [103, 104], by an E3 SCF complex containing the F-box protein FBXW7 (Cdc4 in Saccharomyces cerevisae, SEL-10 in Caenorhabditis elegans) [105]. Co-expression of FBXW7 and APP causes increased presenilin ubiquitylation and elevated $\mathrm{A} \beta$ production. Whether this is a result of ubiquitylation of full length presenilins or the enzymatically active fragments thereof remains controversial [104, 105]. Additionally, the nature of the components of the PS1 SCFFBXw7 complex and the detailed mechanisms that result in PS1 ubiquitylation remain to be resolved. Moreover, it also needs to be established how this activity results in increased levels of $A \beta$.

Humanin is a neuroprotective, 24-amino acid polypeptide that is capable of specifically suppressing ADrelated neurotoxicity caused by the presence of PS1 and APP mutants [106, 107]. Elevated levels of humanin are found in brain tissue of $\mathrm{AD}$ patients relative to agematched controls [108]. The mechanisms behind the protective effects of humanin remain unclear. Recent studies have indicated that it can prevent Bax activation, thereby suppressing mitochondrial stress-induced apoptosis [109]. Furthermore, humanin levels can be down-regulated by the RING E3, TRIM11 [110]. Therefore, humanin presents a possible therapeutic target for controlling AD. Slowing its rate of degradation by TRIM11 may maximise this peptides' therapeutic potential. 


\section{Parkinson's Disease}

PD is the second most common neurodegenerative disease. It is characterised by the loss of dopaminergic neurons in the substantia nigra of the midbrain and the presence of ubiquitin-positive proteinaceous cytoplasmic inclusions, Lewy bodies, in many of the remaining neurons $[2,111]$. The majority of PD cases are apparently sporadic, with only $5-10 \%$ of all cases being inherited [112]. To date, genetic studies have identified mutations in the genes that code for $\alpha$-synuclein, parkin, UCH-L1, DJ-1 and NR4A2 in families with PD [113-117]. The defective gene(s) at other candidate loci remain(s) to be identified $[118,119]$. Although the molecular changes underlying the initiation and progression of sporadic disease are largely unclear, there is now strong evidence that implicates abnormal processing of a variety of cellular proteins via the UPS in PD development. In fact, in the familial forms of PD, $\alpha$-synuclein, parkin, UCH-L1 and DJ-1 are associated with the UPS, parkin and UCH-L1 as components of the system, modified and/or mutant $\alpha$-synuclein and DJ-1 as targets [120-122].

Parkin mutations account for about $50 \%$ of cases of autosomal recessive juvenile parkinsonism (AR-JP) [123] and a small number of apparently sporadic cases of PD [124-126]. Unlike sporadic PD, Lewy body pathology is apparently absent in brain tissue of AR-JP patients [77, 127]. Parkin is a RING type E3 [54]. Two RING domains are separated by an additional Cys/His-rich region termed the 'in between RING finger' (IBR) domain [128], a domain which is found in a number of other proteins including dorfin, HHARI and H7-AP1/Parc [69, 129]. Disease-associated mutations within the RING-IBRRING domain of parkin inhibit interaction with the E2s $\mathrm{UbcH} 7$ or UbcH8 thereby inhibiting its E3 activity [54, $130,131]$. Consequently, the failure of parkin to ubiquitylate target proteins may lead to their accumulation. In turn, this may lead to the formation of aggregates that are toxic to neurons of the substantia nigra.

To date, 9 targets of parkin-mediated degradation have been identified; CDCrel-1 [131], Pael-R [132], synphilin1 [6], $\alpha$-synuclein [121] and/or a glycosylated form of $\alpha$ synuclein, termed $\alpha$ Sp22 [120], cyclin E [133], $\alpha / \beta$ tubulin [134], the p38 subunit of the aminoacyl-tRNA synthase complex (p38) [135], SEPT5_v2 [136] and synaptotagmin XI [137]. The significance of parkin-targeted ubiquitylation of these proteins with respect to PD remains largely unclear. Whereas some are found in Lewy bodies, others accumulate in the brains of AR-JP patients [121, 132, $135,138,139]$. Furthermore, proteins such as $\alpha$-synuclein and Pael-R are known to be natively unfolded, prone to aggregation and cause toxicity in neuronal cells [71, 132, 140-142]. Moreover, mutant (but not wild-type) $\alpha$-synuclein has been reported to inhibit proteasome activity [9, 141, 143]. Interestingly, parkin is capable of suppressing the neurotoxicity of both $\alpha$-synuclein and Pael-R [141, 142]. This indicates a role for parkin in both sporadic and hereditary forms of PD. In sporadic disease, parkin may become sequestered into Lewy bodies by target proteins including (mutant) $\alpha$-synuclein and Pael-R. In parkinassociated disease, lack of E3 activity that results in increased substrate levels may lead to the formation of highly toxic protein aggregates. The potency of these toxic aggregates may lead to such a rapid cell death that the remaining neurons do not present aggresome-related Lewy bodies.

Additional E3s may have a significant role in PD. The U-box E3, CHIP, interacts with, and enhances the ubiquitylation of, the Pael-R by parkin [71]. Additionally, dorfin and the RING E3 Siah-1 are both capable of targeting synphilin-1 for degradation [144, 145]. Indeed, Siah-1-mediated ubiquitylation of synphilin-1 was more efficient than that of parkin [145]. Interestingly, with respect to parkin specificity, neither dorfin nor Siah-1 can directly ubiquitylate $\alpha$-synuclein.

Mutations in the DUB UCH-L1, which drastically reduce its enzymatic activity, cause autosomal dominant PD in a German kindred [115]. However, a rather surprising observation was that UCH-L1 also possesses E3 activity towards $\alpha$-synuclein in vitro [146]. This ATPindependent process required UCH-L1 dimerisation. An S18Y polymorphism, which is associated with decreased risk of PD, displayed reduced E3 activity [146]. Furthermore, UCH-L1 E3 activity towards $\alpha$-synuclein generated Lys63 polyubiquitin chains. Taken together, Liu et al. [146] suggested that UCH-L1 may possess both a beneficial hydrolase activity and a dimerisation-dependent ligase activity, which may be pathologically detrimental. It will now be important to confirm the dual activities of $\mathrm{UCH}-\mathrm{L} 1 \mathrm{in}$ vivo.

\section{Amyotrophic Lateral Sclerosis}

Amyotrophic lacteral sclerosis (ALS) is the most common motor neuron disorder. It begins in the fifth or sixth decade of life. Death usually then occurs within 5 years. ALS is characterised by a loss of motor neurons in the cerebral cortex, brain stem and spinal cord. Prior to cell death, neurons of ALS patients contain ubiquitin-positive 
hydraline and skein-like inclusions [147-149]. Although the majority of ALS cases are sporadic, $10 \%$ of patients have familial disease. Autosomal dominant mutations in the SOD1 gene account for up to $20 \%$ of these inherited cases [150]. SOD1 encodes the superoxide dismutase 1 protein that is involved in free radical scavenging. Similar to other neurodegenerative-associated proteins, mutant SOD1 has a high propensity to misfold and aggregate [reviewed in ref. 151]. Whilst the precise mechanisms underlying SOD1-related disease remain unclear, there is an increasing body of evidence indicating that mutant SOD1 causes mitochondrial dysfunction and inhibition of the proteasome [152-155]. Recent immunohistochemical analysis revealed that the RING-IBR-RING protein, dorfin, localised within the inclusions of ALS patients and interacted with mutant, but not wild-type SOD1 [13, 149]. Furthermore, Niwa et al. [13] used neuronal cell culture systems to demonstrate that dorfin displayed protective properties against mutant SOD1-mediated toxicity. It targeted mutant SOD1 for $26 \mathrm{~S}$ proteasomal degradation, thereby reducing the number of inclusion bodies [13]. Hence, regulation of dorfin E3 activity may be beneficial in the treatment of ALS.

\section{Polyglutamine Disorders}

A number of neurodegenerative conditions caused by expanded polyglutamine (polyQ)-encoding CAG repeats have been identified. All are characterised by a toxic gain of function of the disease-associated expanded polyQ protein and the development of ubiquitin-positive neuronal intracellular inclusions and eventual cell death of a subset of neurons [156, 157]. Interestingly, overexpression of parkin reduced the number of inclusions and cytotoxicity observed in cells expressing an expanded polyQ repeat [158]. However, these cell culture conditions represented somewhat artificial conditions. Therefore, it is now essential to determine whether such observations can be replicated in transgenic animals. If so, these data would suggest that modulation of parkin activity would represent a therapeutic option for treatment of at least some of these conditions.

\section{Huntington's Disease}

$\mathrm{HD}$ is the most common and best characterised of the polyQ disorders. This autosomal dominant disease presents with progressive, selective loss of striatal neurons associated with choreic movements and dementia. The disease is associated with increases in the length of a CAG triplet repeat present in the huntingtin gene located on chromosome 4p16.3. Normal subjects contain between 11 and 34 polyQ repeats within huntingtin. By contrast, HD patients generally have more than 40 [159]. Pathologically, affected neurons contain intranuclear ubiquitylated inclusions $[160,161]$. Moreover, huntingtin is also found to be ubiquitylated in patients, transgenic mice and cell culture systems [7, 10,160-162]. The function of huntingtin is unknown. A range of functions that include roles in vesicle trafficking, signal transduction and transcription have been proposed [for a recent review, see ref. 163].

Many groups have utilised the yeast-2-hybrid system in an attempt to identify huntingtin-interacting proteins. One such protein was the E2, E2-25K (HIP-2) [162]. However, its interaction with huntingtin was not affected by the length of the polyQ repeats. In a separate study, HIP-2 was found to interact with 4 RING finger proteins; RNF2, RNF24, HIPI-8 and HSD-4 [164]. Although RNF2 demonstrated E3 activity, it is not known whether huntingtin is an RNF2 substrate. It was not established whether the other RING finger proteins are E3s. Since huntingtin is ubiquitylated, and the known huntingtin interactant HIP-2 can bind 4 separate RING finger proteins, these latter molecules may promote the ubiquitylation and degradation of huntingtin. Confirming this hypothesis will necessitate further detailed investigation.

\section{Spinocerebellar Ataxia Type 1}

Spinocerebellar ataxia type 1 (SCA1) is clinically characterised by ataxia, progressive motor dysfunction and loss of brainstem neurons and cerebellar Purkinje cells. PolyQ expansions of the $S C A 1$ gene, ataxin-1, were found to be responsible for the disorder [165]. Affected neurons of SCA1 patients and transgenic mice contain ubiquitinpositive insoluble nuclear inclusions [166]. Cummings et al. [167] demonstrated that ataxin-1 is a target for the UPS. Furthermore, although expanded ataxin-1 [92Q] was efficiently polyubiquitylated, it was three times more resistant to degradation than ataxin-1 [2Q]. As part of a transgenic study, this group went on to generate transgenic mice with both an expanded ataxin-1 [82Q] and knockout of the maternal allele of the gene encoding HECT E3, E6-AP1. These double-mutant mice displayed a more severe pathological phenotype. Neuronal damage occurred at more than four times the rate of the ataxin-1 [82Q] mice despite having less nuclear inclusions than their ataxin-1 [82Q] littermates [167]. These data indicated that impairment of the proteasome rather than the presence of nuclear inclusions was a prerequisite for neu- 
rodegeneration. This study provides further evidence that the presence of inclusions may be a cell's attempt to protect itself rather than represent a deleterious mechanism. Surprisingly, E6-AP1 could not ubiquitylate ataxin-1 in vitro [167]. E6-AP1 may require additional but as yet unidentified in vivo factors to target ataxin-1 degradation. Alternatively, the effects observed in the doublemutant mice may be caused indirectly due to E6-AP1 ubiquitylation of ataxin-1-regulatory proteins.

\section{Spinobulbar Muscular Atrophy}

Spinobulbar muscular atrophy (SBMA or Kennedy disease) is caused by polyQ expansions in the androgen receptor (AR). The consequence is motor neuronal cell loss and subsequent progressive muscle weakness [168]. The AR is an androgen-dependent member of the steroid receptor superfamily responsible for transcriptional regulation of androgen-responsive genes [169, 170]. The functions of many nuclear receptors including oestrogen receptor alpha are controlled by the UPS [171, 172]. Ubiquitylated nuclear inclusions have been described in motor neurons of SBMA patients and in transgenic mice overexpressing expanded polyQ repeats [173-175]. In cell culture systems, blocking the generation of mutant AR aggresomes was found to be deleterious to cells, suggesting cytoprotective properties of such inclusions [84].

$\mathrm{AR}$ interacts with 3 RING finger proteins - SNURF/ RNF4, ARA54 and ARNIP [176, 177]. Interestingly, each of these RING finger proteins binds to a different domain of AR. SNURF binds to the central domain. This region is required for binding androgen response elements on DNA. This hormone-dependent interaction allows both AR-dependent transactivation and also basal transcription from steroid-regulated promoters [176]. ARA54 is a RING-IBR-RING protein that interacts with the C-terminal steroid specificity domain of AR. ARA54 can enhance the transcriptional activity of wild-type and mutant AR [178]. Perhaps most interesting with respect to SBMA, however, is the interaction between AR and ARNIP (AR N-terminal-interacting protein) [177]. ARNIP, as the name suggests, binds to the $\mathrm{N}$-terminal transcription regulation and polyQ-containing domain. ARNIP interacts with polyQ repeats in both the normal (9-36 repeats) and SBMA disease-associated range (40-62 repeats). In mammalian cells, ARNIP was found to colocalise with AR and in response to androgen stimulation, both were located within the nuclei [177]. Unlike SNURF and ARA54, ARNIP does not appear to act as a coactivator or corepressor of transactivation. By contrast, it displays E3 activity in in vitro ubiquitylation assays [177].
A number of other proteins including BRCA1 and E6-AP1 can act as both E3s and coactivators of the steroid receptor superfamily [179, 180]. Given the complex interplay between SNURF, ARA54, ARNIP and AR, their known functions and the fact that expanded polyQ repeats are commonly more resistant to degradation than the wild-type protein, it is now crucial to establish whether there is an E3 role for these RING finger proteins, in particular ARNIP, in AR-mediated degradation.

\section{Dentatorubral-Pallidoluysian Atrophy}

Dentatorubral-pallidoluysion atrophy (DRPLA) is a progressive familial disorder caused by a polyQ expansion in the atrophin-1 gene on chromosome 12p13.31 $[181,182]$. Whereas 6-35 CAG repeats is normal, DRPLA patients have 49-88 [182, 183]. Little is known of the function of mammalian atrophin-1; Drosophila atrophin-1 (Grunge) acts as a transcriptional corepressor with multiple roles in fly development including correct segmentation during embryogenesis [184, 185]. Interestingly, human atrophin-1 forms cytoplasmic lesions that are ubiquitylated in DRPLA but not in control brains [186]. Furthermore, atrophin-1 was found to interact with 3 NEDD4-like HECT domain proteins, i.e. AIP2/WWP2, AIP4/ITCH and AIP5/WWP1 [187]. Both normal and pathological polyQ repeats interacted with these HECT E3s [187]. Although it is yet to be determined, it seems highly likely that atrophin-1 may be a target for AIP-2, -4 or -5 mediated proteolytic destruction given the functional nature of HECT domain proteins. Indeed, similar to observations in HD, disease-associated CAG expansions may be more resistant to degradation than repeats within the normal range, resulting in blockage of proteasomal activity at times of stress [188]. If this is the case, given the high degree of selectivity of the UPS, it is perhaps puzzling that 1 protein should require 3 different E3s to promote its efficient degradation. It raises the possibility that atrophin-1 is an E3-associated protein that aids the target selection. RING E3s can cooperate to catalyse ubiquitylation [189-191]. Moreover, AIP-4 can interact with the RING E3, cCBL to regulate EGFR signalling [192]. Therefore, levels of atrophin-1 may be tightly regulated by different HECT proteins in response to different environmental stimuli. 


\section{Prion Diseases}

Mutations in the prion protein $(\mathrm{PrP})$ gene are associated with a diverse transmissible, heritable and sporadic group of spongiform neurodegenerative disorders including Gerstmann-Straussler disease and Creutzfeldt-Jakob disease. PrP is a widely expressed cell surface glycoprotein of unknown function [193, 194]. PrPC, the normal form of the protein, is soluble and highly sensitive to proteases. During the disease process, wild-type or mutant $\operatorname{PrP}^{\mathrm{C}}$ undergoes conformational changes to form $\mathrm{PrPSc}$, which is highly prone to aggregate and form insoluble, proteaseresistant inclusions within the cytoplasm of neuronal cells [193-195].

Mahogunin is a RING E3 responsible for the mahoganoid coat colour mutation in mice [196, 197]. Mice carrying a null mutation for mahoganoid developed age-dependent spongiform neuropathology as well as an altered coat colour. This pathology resembled that observed in prion diseases but lacked the accumulation of protease-resistant PrP [197]. PrP itself does not appear to be a target for mahogunin-mediated ubiquitylation and degradation [197]. It will be interesting to see whether disease-associated mutant PrP or regulators of PrP metabolism are mahogunin targets of the UPS.

\section{Lafora Disease}

Lafora disease (LD) is the most common and severe form of adolescent-onset progressive myoclonus epilepsy. This autosomal recessive disorder causes rapid and severe neurodegeneration, ataxia and myoclonus epilepsy. Affected individuals usually fail to survive more than 10 years after onset. The disease is characterised by an accumulation of starch-like polyglucosans, or Lafora bodies, within the endoplasmic reticulum in both neuronal and non-neuronal cell types [198-200]. These inclusions are found in dendrites but not axons [200, 201]. Interestingly, they are ubiquitin positive exclusively in neuronal cells, suggesting different processing and pathological consequences for Lafora inclusions in these tissues [198, 199].

To date, 2 genes have been identified with linkage to the disorder [200, 202]. $70 \%$ of individuals with LD carry mutations in EPM2A, on chromosome 6q24 that encodes laforin, a dual-specificity phosphatase [201,202]. Generation of Epm $2 a$ knockout mice demonstrated that neuronal degeneration and Lafora inclusion bodies predate the onset of impaired behavioural responses associated with this disease [199]. Chan et al. [200] have recently identified a second locus responsible for LD, $E P M 2 B$ (NHLRC1), which encodes malin, a RING-finger-containing protein. Although little is known about the role of malin, given the presence of the RING motif, it may function as an E3. Disease-associated mutations in malin may lead to the accumulation of polyglucosans and dendritic protein targets causing disruption of neuronal synaptic function and subsequent dementia, neurologic deterioration and epilepsy.

\section{Other Components of the UPS Associated with Neurodegenerative Disorders}

Several other UPS proteins have been identified that may be linked to the development of a number of other neurodegenerative conditions. Machado-Joseph disease is a polyQ disease caused by expansions of the ataxin-3 protein. Ataxin-3 can interact with DNA repair proteins HHR23A and HHR23B via their ubiquitin-like domains [203] and possesses DUB activity [204]. In addition, ataxin-7, a polyQ-containing protein associated with spinocerebellar ataxia type 7 , associates with the 19 S proteasomal subunit S4 [205].

Ubiquitin-related proteins such as SUMO, and the ubiquitin-binding protein p62, are commonly found in the pathological inclusions associated with neurodegenerative diseases [206-209]. In AD, $A \beta$ may be involved in up-regulating ubiquitylation and/or down-regulating proteasome activity [210-212]. Mutant $\alpha$-synuclein, associated with familial PD, is also thought to down-regulate proteasome activity [9, 141, 143]. Furthermore, proteolysis of both tau and $\alpha$-synuclein can occur via proteasomal mechanisms independently of ubiquitylation [213, 214].

Another layer of complexity associated with $\mathrm{AD}$, and possibly other neurodegenerative disorders, is molecular misreading [215-219]. This age-related process occurs through the generation of a transcript from a normal gene, but which loses one or more base pairs during the transcriptional process. In AD patients, novel frameshift mutations in the ubiquitin $B$ gene lead to the translation of novel but nonsense peptide sequences creating 'ubiquitin +1 '. Although ubiquitin +1 can act as an acceptor for additional ubiquitin molecules, it cannot donate itself to an expanding polyubiquitin chain as it has lost its Cterminal glycine residue. This mutant form of ubiquitin blocks proteasomal degradation [219] and causes neuronal cell death [217]. 


\section{Concluding Remarks}

Ubiquitin-proteasome-mediated processes clearly play an important role in many neurological disorders. Recent elucidation of RING motif-containing proteins, the fourth most abundant protein domain in the human genome, as a major class of E3s has rapidly broadened our understanding of many disease processes over the past few years. Neurodegenerative diseases are no exception to this and a number of E3 proteins have been identified to be associated with neurodegeneration. Although enzymatic activity of a number of others need to be confirmed, these proteins are highly likely to be E3s. Obviously, it is now paramount that these proposals are confirmed in vivo.

The molecular basis for the tissue-specific effects observed as a result of a malfunctioning UPS are not understood. Many E3s are ubiquitously expressed and they can target different substrates in the same cell. Tissue-specific effects may be exacerbated in neurons as they are terminally differentiated cells and generally do not self-renew. Moreover, there may be degeneracy in substrate targeting in different cells by different E3s. However, these possibilities cannot fully explain why specific populations of neuronal cells are targeted for damage and/or loss in a given neurodegenerative disorder. For example, PD is associated with loss of the dopaminergic cells of the substantia nigra in both sporadic and familial forms of disease including AR-JP. Parkin, mutations in which cause AR$\mathrm{JP}$, is found in multiple tissues, yet mutant parkin only exerts obvious phenotypic effects in the substantia nigra.
Why? Studies aimed at identifying which key substrate, of potentially many, of a particular E3 is not processed appropriately will be of paramount importance in answering such questions.

From a treatment perspective, it is exciting to realise that inappropriate activity of a single E3 may be associated with more than one disease. For example, dorfin can ubiquitylate proteins associated with both PD and ALS; parkin plays a crucial role in $\mathrm{PD}$, but may also be active in polyQ disorders. Furthermore, more than one E3 may be associated with a particular disease. From our current understanding, parkin appears to be the principal E3 associated with hereditary PD. What are the roles, if any, of dorfin, Siah-1 or other E3s in disease progression? CHIP can enhance parkin E3 activity. Perhaps other E3s can also interact to enhance/inhibit specific ubiquitylation events during PD.

Understanding the complex mechanisms involved in the recognition and specific targeting of both normal and mutant proteins may provide insights into how we can develop therapeutic strategies to degrade precisely a single protein within a diseased cell [21].

\section{Acknowledgements}

H.C.A. is a recipient of a 'Research into Ageing' Fellowship award. Work in the authors' laboratory is also supported by The Wellcome Trust, The Royal Society and Yorkshire Cancer Research. We would like to thank Drs. G.B. Scott and S.A. Rose for their critical reading of the manuscript and their helpful suggestions.

\section{References}

1 UK 2001 census, National Statistics: http:// www.statistics.gov.uk/cci/nugget.asp?id $=287$.

$>2$ Lowe J, Blanchard A, Morrell K, Lennox G, Reynolds L, Billett M, Landon M, Mayer RJ: Ubiquitin is a common factor in intermediate filament inclusion bodies of diverse type in man, including those of Parkinson's disease, Pick's disease, and Alzheimer's disease, as well as Rosenthal fibres in cerebellar astrocytomas, cytoplasmic bodies in muscle, and Mallory bodies in alcoholic liver disease. J Pathol 1988; 155:9-15

$\checkmark 3$ Kaytor MD, Warren ST: Aberrant protein deposition and neurological disease. J Biol Chem 1999;274:37507-37510.

$\checkmark 4$ Sherman MY, Goldberg AL: Cellular defenses against unfolded proteins: A cell biologist thinks about neurodegenerative diseases. Neuron 2001;29:15-32.
5 Johnston JA, Ward CL, Kopito RR: Aggresomes: A cellular response to misfolded proteins. J Cell Biol 1998;143:1883-1898.

6 Chung KKK, Zhang Y, Lim KL, Tanaka Y, Huang H, Gao J, Ross CA, Dawson VL, Dawson TM: Parkin ubiquitinates the $\alpha$-synucleininteracting protein, synphilin-1:Implications for Lewy-body formation in Parkinson disease. Nat Med 2001;7:1144-1150.

$\checkmark 7$ Martin-Aparicio E, Yamamoto A, Hernandez F, Hen R, Avila J, Lucas JJ: Proteasomaldependent aggregation reversal and absence of cell death in a conditional mouse model of Huntington's disease. J Neurosci 2001;21: 8772-8781.

$\checkmark 8$ O'Farrell C, Murphy DD, Petrucelli L, Singleton $\mathrm{AB}$, Hussey J, Farrer M, Dickson DW, Cookson MR: Transfected synphilin-1 forms cytoplasmic inclusions in HEK293 cells. Mol Brain Res 2001;97:94-102.
-9 Tanaka Y, Engelender S, Igarashi S, Rao RK, Wanner T, Tanzi RE, Sawa A, Dawson VL, Dawson TM, Ross CA: Inducible expression of $\alpha$-synuclein decreases proteasome activity and increases sensitivity to mitochondria-dependent apoptosis. Hum Mol Genet 2001;10:919_ 926.

10 Waelter S, Boeddrich A, Lurz R, Scherzinger E, Lueder G, Lehrach H, Wanker EE: Accumulation of mutant huntingtin fragments in aggresome-like inclusion bodies as a result of insufficient protein degradation. Mol Biol Cell 2001; 12:1393-1407.

11 Lee H-J, Shin SY, Choi C, Lee YH, Lee S-J: Formation and removal of $\alpha$-synuclein aggregates in cells exposed to mitochondrial inhibitors. J Biol Chem 2002;277:5411-5417. 
12 Junn E, Lee SS, Suhr UT, Mouradian MM: Parkin accumulation in aggresomes due to proteasome impairment. J Biol Chem 2002;277: 47870-47877.

13 Niwa J-i, Ishigaki S, Hishikawa N, Yamamoto M, Doyu M, Murata S, Tanaka K, Taniguchi N, Sobue G: Dorfin ubiquitylates mutant SOD1 and prevents mutant SOD1-mediated neurotoxicity. J Biol Chem 2002·277:39793 36798.

14 Walsh DM, Klyubin I, Fadeeva JV, Cullen WK, Anwyl R, Wolfe MS, Rowan MJ, Selkoe DJ: Naturally secreted oligomers of amyloid $\beta$ protein potently inhibit hippocampal longterm potentiation in vivo. Nature 2002;416 535-539.

-15 Ardley HC, Scott GB, Rose SA, Tan NGS, Markham AF, Robinson PA: Inhibition of proteasomal activity causes inclusion formation in neuronal and non-neuronal cells over-expressing Parkin. Mol Biol Cell 2003;14:4541-4556.

-16 Goto S, Takahashi R, Kumiyama A, Radak Z, Hayashi T, Takenouchi M, Abe R: Implications of protein degradation in aging. Ann NY Acad Sci 2001;928:54-64.

17 Mayer RJ: From neurodegeneration to neurohomeostasis: The role of ubiquitin. Drug News Perspect 2003;16:103-108.

18 Berke SJ, Paulson HL: Protein aggregation and the ubiquitin proteasome pathway: Gaining the UPPer hand on neurodegeneration. Curr Opin Genet Dev 2003;13:253-261.

19 Gray DA, Tsirigotis M, Woulfe J: Ubiquitin, proteasomes, and the aging brain. Sci Aging Knowledge Environ 2003;34:RE6.

20 Layfield R, Cavey JR, Lowe J: Role of ubiquitin-mediated proteolysis in the pathogenesis of neurodegenerative disorders. Ageing Res Rev 2003;2:343-356.

21 Robinson PA, Ardley HC: Ubiquitin protein ligases: Novel therapeutic targets? Curr Protein Pept Sci, in press.

-22 Johnson JL, Craig EA: Protein misfolding in vivo: Unraveling complex pathways. Cell 1997 ; 90:201-204

-23 Feder ME, Hofmann GE: Heat shock proteins, molecular chaperones and the stress response: Evolutionary and ecological physiology. Annu Rev Physiol 1999;61:243-282.

-24 Schubert U, Anton LC, Gibbs J, Norbury CC, Yewdell JW, Bennink JR: Rapid degradation of a large fraction of newly synthesized proteins by proteasomes. Nature 2000;404:770-774.

-25 Pickart CM: Mechanisms underlying ubiquitination. Annu Rev Biochem 2001;70:503-533.

26 Weissman AM: Themes and variations on ubiquitylation. Nat Rev Mol Cell Biol 2001;2: 169-178.

-27 Doherty FJ, Dawson S, Mayer RJ: The ubiquitin-proteasome pathway of intracellular proteolysis. Essays Biochem 2002;38:51-63.

28 Wojcik C: Regulation of apoptosis by the ubiquitin and proteasome pathway. J Cell Mol Med 2002;6:25-48

29 Muratani M, Tansey WP: How the ubiquitinproteasome system controls transcription. Nat Rev Mol Cell Biol 2003;4:192-201.
30 Varshavsky A: The N-end rule and regulation of apoptosis. Nat Cell Biol 2003;5:373-376.

31 Goldberg AL, Rock KL: Proteolysis, proteasomes and antigen presentation. Nature 1992; 357:45-46.

32 Kloetzel P-M: Antigen processing by the proteasome. Nat Rev Mol Cell Biol 2001;2:179_ 187.

33 Chung $\mathrm{CH}$, Baek SH: Deubiquitinating enzymes: Their diversity and emerging roles. Biochem Biophys Res Commun 1999;266:633640.

34 Baek KH: Conjugation and deconjugation of ubiquitin regulating the destiny of proteins. Exp Mol Med 2003;35:1-7.

- 35 Wilkinson KD, Lee KM, Deshpande S, Duerksen-Hughes P, Boss JM, Pohl J: The neuron-specific protein PGP 9.5 is a ubiquitin carboxyl-terminal hydrolase. Science 1989;246: 670-673.

36 Hicke L: Protein regulation by monoubiquitin. Nat Rev Mol Cell Biol 2001;2:195-201.

37 Karin M: How NF-kappaB is activated: The role of the IkappaB kinase (IKK) complex. Oncogene 1999;18:6867-6874.

38 Fujita Y, Krause G, Scheffner M, Zechner D, Leddy HE, Behrens J, Sommer T, Birchmeier W: Hakai, a c-Cbl-like protein, ubiquitinates and induces endocytosis of the E-cadherin complex. Nat Cell Biol 2002;4:222-231.

-39 Huibregtse JM, Scheffner M, Beaudenon S, Howley PM: A family of proteins structurally and functionally related to the E6-AP ubiquitin protein ligase. Proc Natl Acad Sci USA 1995; 92:2563-2567.

40 Borden KL: RING domains: Master builders of molecular scaffolds? J Mol Biol 2000;295: 1103-1112.

41 Freemont PS: RING for destruction? Curr Biol 2000; 10:R84-R87.

$\checkmark 42$ Jackson PK, Eldridge AG, Freed E, Furstenthal L, Hsu JY, Kaiser BK, Reimann JD: The lore of the RINGs: Substrate recognition and catalysis by ubiquitin ligases. Trends Cell Biol 2000; 10:429-439

43 Scheffner M, Huibregtse JM, Vierstra RD, Howley PM: The HPV-16 E6 and E6-AP complex functions as a ubiquitin-protein ligase in the ubiquitination of p53. Cell 1993;75:495505.

44 Kumar S, Kao WH, Howley PM: Physical interaction between specific E2 and Hect E3 enzymes determines functional cooperativity. $\mathrm{J}$ Biol Chem 1997;272:13548-13554.

45 Nuber U, Scheffner M: Identification of determinants in E2 ubiquitin-conjugating enzymes required for hect E3 ubiquitin-protein ligase interaction. J Biol Chem 1999;274:75767582.

46 Rotin D, Staub O, Haguenauer-Tsapis R: Ubiquitination and endocytosis of plasma membrane proteins: Role of Nedd4/Rsp5p family of ubiquitin-protein ligases. $\mathrm{J}$ Membr Biol 2000; 176:1-17.

47 Kavsak P, Rasmussen RK, Causing CG, Bonni S, Zhu H, Thomsen GH, Wrana JL: Smad7 binds to Smurf2 to form an E3 ubiquitin ligase that targets the TGF beta receptor for degradation. Mol Cell 2000;6:1365-1375.
48 International Human Genome Sequencing Consortium: A physical map of the human genome. Nature 2001;409:860-921.

49 Tyers M, Jorgensen P: Proteolysis and the cell cycle: With this RING I do thee destroy. Curr Opin Genet Dev 2000;10:54-64.

50 Joazeiro CA, Weissman AM: RING finger proteins: Mediators of ubiquitin ligase activity. Cell 2000;102:549-552.

51 Lorick KL, Jensen JP, Fang S, Ong AM, Hatakeyama S, Weissman AM: RING fingers mediate ubiquitin-conjugating enzyme (E2)-dependent ubiquitination. Proc Natl Acad Sci USA 1999;96:11364-11369.

52 Joazeiro CA, Wing SS, Huang H, Leverson JD, Hunter T, Liu YC: The tyrosine kinase negative regulator c-Cbl as a RING-type, E2-dependent ubiquitin-protein ligase. Science 1999; 286:309-312.

53 Yokouchi M, Kondo T, Sanjay A, Houghton A, Yoshimura A, Komiya S, Zhang H, Baron R: Src-catalyzed phosphorylation of c-Cbl leads to the interdependent ubiquitination of both proteins. J Biol Chem 2001;276:35185-35193

54 Shimura H, Hattori N, Kubo S, Mizuno Y, Asakawa S, Minoshima S, Shimizu N, Iwai K, Chiba T, Tanaka K, Suzuki T: Familial Parkinson disease gene product, parkin, is a ubiquitinprotein ligase. Nat Genet 2000;25:302-305.

$\checkmark 55$ Seol JH, Feldman RMR, Zachariae W, Shevchenko A, Correll CC, Lyapina S, Chi Y, Claypool J, Sandmeyer S, Nasmyth K, Shevchenko A, Deshaies RJ: Cdc/cullin and the essential Hrt 1 RING-H2 subunit of SCF define a ubiquitin ligase module that activates the E2 enzyme Cdc34. Genes Dev 1999;13:1614-1626.

56 Ohta T, Michel JJ, Schottelius AJ, Xiong Y: ROC1, a homolog of APC11, represents a family of cullin partners with an associated ubiquitin ligase activity. Mol Cell 1999;3:535-541.

57 Leverson JD, Joazeiro CA, Page AM, Huang $\mathrm{H}$, Hieter P, Hunter T: The APC11 RING-H2 finger mediates E2-dependent ubiquitination. Mol Biol Cell 2000;11:2315-2325.

58 Gmachl M, Gieffers C, Podtelejnikov AV, Mann M, Peters JM: The RING-H2 finger protein APC11 and the E2 enzyme UBC4 are sufficient to ubiquitinate substrates of the anaphase-promoting complex. Proc Natl Acad Sci USA 2000;97:8973-8978.

59 Lisztwan J, Imbert G, Wirbelauer C, Gstaiger M, Krek W: The von Hippel-Lindau tumor suppressor protein is a component of an E3 ubiquitin-protein ligase activity. Genes Dev 1999;13:1822-1833.

60 Iwai K, Yamanaka K, Kamura T, Minato N, Conaway RC, Conaway JW, Klausner RD, Pause A: Identification of the von Hippel-Lindau tumor-suppressor protein as part of an active E3 ubiquitin ligase complex. Proc Natl Acad Sci USA 1999;96:12436-12441.

61 Saurin AJ, Borden KLB, Boddy MN, Freemont PS: Does this have a familiar RING? Trends Biochem Sci 1996;21:208-214. 
-62 Kentsis A, Dwyer EC, Perez JM, Sharma M, Chen A, Pan ZQ, Borden KL: The RING domains of the promyelocytic leukemia protein PML and the arenaviral protein $Z$ repress translation by directly inhibiting translation initiation factor eIF4E. J Mol Biol 2001;312: 609-623.

63 Pringa E, Martinez-Noel G, Muller U, Harbers $\mathrm{K}$ : Interaction of the ring finger-related U-box motif of a nuclear dot protein with ubiquitinconjugating enzymes. J Biol Chem 2001;276: 19617-19623.

64 Hatakeyama S, Yada M, Matsumoto M, Ishida N, Nakayama KI: U box proteins as a new family of ubiquitin-protein ligases. J Biol Chem 2001;276:33111-33120.

-65 Murata S, Minami Y, Minami M, Chiba T, Tanaka K: CHIP is a chaperone-dependent E3 ligase that ubiquitylates unfolded protein EMBO Rep 2001;2:1133-1138.

-66 Ohi MD, Vander Kooi CW, Rosenberg JA, Chazin WJ, Gould KL: Structural insights into the U-box, a domain associated with multiubiquitination. Nat Struct Biol 2003;10:250255.

67 Nuber U, Schwarz SE, Scheffner M: The ubiquitin-protein ligase E6-associated protein (E6AP) serves as its own substrate. Eur J Biochem 1998;254:643-649.

-68 Fang S, Jensen JP, Ludwig RL, Vousden KH, Weissman AM: $\mathrm{Mdm} 2$ is a RING fingerdependent ubiquitin protein ligase for itself and p53. J Biol Chem 2000;275:8945-8951.

-69 Niwa J-I, Ishigaki S, Doyu M, Suzuki T, Tanaka K, Sobue G: A novel centrosomal RING-finger protein, Dorfin, mediates ubiquitin ligase activity. Biochem Biophys Res Commun 2001; 281:706-713.

70 Cummings CJ, Mancini MA, Antalffy B, DeFranco DB, Orr HT, Zoghbi HY: Chaperone suppression of aggregation and altered subcellular proteasome localization imply protein misfolding in SCA1. Nat Genet 1998;19:148154.

71 Imai Y, Soda M, Hatakeyama S, Akagi T, Hashikawa T, Nakayama K-I, Takahashi R: $\mathrm{CHIP}$ is associated with Parkin, a gene responsible for familial Parkinson's disease, and enhances its ubiquitin ligase activity. Mol Cell 2002;10:55-67.

72 McLean PJ, Kawamata H, Shariff S, Hewett J, Sharma N, Ueda K, Breakefield XO, Hyman BT: TorsinA and heat shock proteins act as molecular chaperones: Suppression of alphasynuclein aggregation. J Neurochem 2002;83: 846-854.

73 Namba Y, Tomonaga M, Ohtsuka K, Oda M, Ikeda K: HSP 70 is associated with abnormal cytoplasmic inclusions characteristic of neurodegenerative diseases. No To Shinkei 1991; 43:57-60.

74 Renkawek K, Stege GJ, Bosman GJ: Dementia, gliosis and expression of the small heat shock proteins hsp27 and alpha B-crystallin in Parkinson's disease. Neuroreport 1999;10: 2273-2276.
75 Lowe J, McDermott H, Pike I, Spendlove I, Landon M, Mayer RJ: Alpha B crystallin expression in non-lenticular tissues and selective presence in ubiquitinated inclusion bodies in human disease. J Pathol 1992;166:61-68.

76 McNaught K St.P, Shashidharan P, Perl DP, Jenner P, Olanow CW: Aggresome-related biogenesis of Lewy bodies. Eur J Neurosci 2002; $16: 2136-2148$

77 Shimura H, Hattori N, Kubo S, Yoshikawa M, Kitada T, Matsumine H, Asakawa S, Minoshima S, Yamamura Y, Shimizu N, Mizuno Y: Immunohistochemical and subcellular localization of parkin protein: Absence of protein in autosomal recessive juvenile parkinsonism patients. Ann Neurol 1999;45:668-672.

78 Fergusson J, Landon M, Lowe J, Dawson SP, Layfield R, Hanger DP, Mayer RJ: Pathological lesions of Alzheimer's disease and dementia with Lewy bodies brains exhibit immunoreactivity to an ATPase that is a regulatory subunit of the 26S proteasome. Neurosci Lett 1996; 219:167-70.

79 Ii K, Ito H, Tanaka K, Hirano A: Immunocytochemical co-localization of the proteasome in ubiquitinated structures in neurodegenerative diseases and the elderly. J. Neuropathol. Exp Neurol 1997;56:125-131.

80 Arima K, Mizutani T, Alim MA, TonozukaUehara H, Izumiyama $\mathrm{Y}$, Hirai S, Ueda K: NACP/alpha-synuclein and tau constitute two distinctive subsets of filaments in the same neuronal inclusions in brains from a family of parkinsonism and dementia with Lewy bodies: Double-immunolabeling fluorescene and electron microscopic studies. Acta Neuropathol 2000;100:115-121.

81 Seitelberger F, Lassmann H, Bancher C: Cytoskeleton pathology in Alzheimer's disease and related disorders. J Neural Transm Suppl 1991; 33:27-33.

82 Jensen PH, Islam K, Kenney J, Nielsen MS, Power J, Gai WP: Microtubule-associated protein $1 \mathrm{~B}$ is a component of cortical Lewy bodies and binds alpha-synuclein filaments. J Biol Chem 2000;275:21500-21507.

83 Nakazato Y, Sasaki A, Hirato J, Ishida Y: Immunohistochemical localization of neurofilament protein in neuronal degenerations. Acta Neuropathol 1984;64:30-36.

84 Taylor JP, Tanaka F, Robitschek J, Sandoval CM, Taye A, Markovic-Plese S, Fischbeck KH: Aggresomes protect cells by enhancing the degradation of toxic polyglutamine-containing protein. Hum Mol Genet 2003;749-757.

85 Cookson MR, Lockhart PJ, McLendon C, O'Farrell C, Schlossmacher, Farrer MJ: RING finger 1 mutations in Parkin produce altered localization of the protein. Hum Mol Genet 2003;2957-2965.

86 Garcia-Mata R, Bebok Z, Sorscher EJ, Sztul ES: Characterization and dynamics of aggresome formation by a cytosolic GFP-chimera. J Cell Biol 1998;146:1239-1254.

87 Kopito RR: Aggresomes, inclusion bodies and protein aggregation. Trends Cell Biol 2000;10: 524-530.
88 Garcia-Mata R, Gao Y-S, Sztul E: Hassles with taking out the garbage: Aggravating aggresomes. Traffic 2002;3:388-396.

89 Muralidhar MG, Thomas JB: The Drosophila bendless gene encodes a neural protein related to ubiquitin-conjugating enzymes. Neuron 1993;11:253-266.

$\checkmark 90$ Oh CE, McMahon R, Benzer S, Tanouye MA: Bendless, a Drosophila gene affecting neuronal connectivity, encodes a ubiquitin-conjugating enzyme homolog. J Neurosci 1994;14: 3166-3179.

91 Aguilera M, Oliveros M, Martinez-Padron M, Barbas JA, Ferrus A: Ariadne-1: A vital Drosophila gene is required in development and defines a new conserved family of ring-finger proteins. Genetics 2000;155:1231-44.

92 Huang Y, Baker RT, Fischer-Vize JA: Control of cell fate by a deubiquitinating enzyme encoded by the fat facets gene. Science 1995; 270:1828-1831.

93 Kishino T, Lalande M, Wagstaff J: UBE3A/ E6-AP mutations cause Angelman syndrome. Nat Genet 1997;15:70-73.

94 Matsuura T, Sutcliffe JS, Fang P, Galjaard RJ, Jiang YH, Benton CS, Rommens JM, Beaudet AL: De novo truncating mutations in E6-AP ubiquitin-protein ligase gene (UBE3A) in Angelman syndrome. Nat Genet 1997;15: 74-77.

95 Glenner GG, Wong CW: Alzheimer's disease: Initial report of the purification and characterisation of a novel cerebrovascular amyloid protein. Biochem Biophys Res Commun 1984;120:885-890.

$\checkmark 96$ Wischik CM, Novak M, Edwards PC, Klug A, Tichelaar W, Crowther RA: Structural characterization of the core of the paired helical filament of Alzheimer disease. Proc Natl Acad Sci USA 1988;85:4884-4888.

$\$ 97$ Perry G, Friedman R, Shaw G, Chau V: Ubiquitin is detected in neurofibrillary tangles and senile plaque neurites of Alzheimer disease brains. Proc Natl Acad Sci USA 1987; 84:3033-3036.

-98 St George-Hyslop PH, Tanzi RE, Polinsky RJ, Haines JL, Nee L, Watkins PC, Myers RH, Feldman RG, Pollen D, Drachman D, et al: The genetic defect causing familial Alzheimer's disease maps on chromosome 21. Science 1987;235:885-890.

-99 Sherrington R, Rogaev EI, Liang Y, Rogaeva EA, Levesque G, Ikeda M, Chi H, Lin C, Li $\mathrm{G}$, Holman K, et al: Cloning of a gene bearing missense mutations in early-onset familial Alzheimer's disease. Nature 1995;375:754760.

100 Levy-Lahad E, Wasco W, Poorkaj P, Romano DM, Oshima J, Pettingell WH, Yu CE, Jondro PD, Schmidt SD, Wang K, et al: Candidate gene for the chromosome 1 familial Alzheimer's disease locus. Science 1995;269: 973-977.

101 Esler WP, Wolfe MS: A portrait of Alzheimer secretases - New features and familiar faces. Science 2001;293:1449-1454. 
102 Selkoe DJ: Presenilin, Notch, and the genesis and treatment of Alzheimer's disease. Proc Natl Acad Sci USA 2001;98:11039-11041.

-103 Kim TW, Pettingell WH, Hallmark OG, Moir RD, Wasco W, Tanzi RE: Endoproteolytic cleavage and proteasomal degradation of presenilin 2 in transfected cells. J Biol Chem 1997;272:11006-11010.

104 Steiner H, Capell A, Pesold B, Citron M, Kloetzel PM, Selkoe DJ, Romig H, Mendla $\mathrm{K}$, Haass C: Expression of Alzheimer's disease-associated presenilin-1 is controlled by proteolytic degradation and complex formation. J Biol Chem 1998;273:32322-32331.

105 Li J, Pauley AM, Myers RL, Shuang R, Brashler JR, Yan R, Buhl AE, Ruble C, Gurney ME: SEL-10 interacts with presenilin 1, facilitates its ubiquitination, and alters Abeta peptide production. J Neurochem 2002; 82:1540-1548

106 Hashimoto Y, Niikura T, Tajima H, Yasukawa T, Sudo H, Ito Y, Kita Y, Kawasumi M, Kouyama K, Doyu M, Sobue G, Koide T, Tsuji S, Lang J, Kurokawa K, Nishimoto I: A rescue factor abolishing neuronal cell death by a wide spectrum of familial Alzheimer's disease genes and Abeta. Proc Natl Acad Sci USA 2001;98:6336-6341.

107 Hashimoto Y, Niikura T, Ito Y, Sudo H, Hata M, Arakawa E, Abe Y, Kita Y, Nishimoto I: Detailed characterization of neuroprotection by a rescue factor humanin against various Alzheimer's disease-relevant insults. J Neurosci 2001;21:9235-9245.

- 108 Tajima H, Niikura T, Hashimoto Y, Ito Y, Kita Y, Terashita K, Yamazaki K, Koto A, Aiso S, Nishimoto I: Evidence for in vivo production of Humanin peptide, a neuroprotective factor against Alzheimer's disease-related insults. Neurosci Lett 2002;324:227-231.

- 109 Guo B, Zhai D, Cabezas E, Welsh K, Nouraini S, Satterthwalt AC, Reed JC: Humanin peptide suppresses apoptosis by interfering with Bax activation. Nature 2003;423:456461.

110 Niikura T, Hashimoto Y, Tajima H, Ishizaka M, Yamagishi Y, Kawasumi M, Nawa M, Terashita K, Aiso S, Nishimoto I: A tripartite motif protein TRIM11 binds and destabilizes Humanin, a neuroprotective peptide against Alzheimer's disease-relevant insults. Eur J Neurosci 2003;17:1150-1158.

$\checkmark 111$ Lang AE, Lozano AM: Parkinson's disease. First of two parts. N Engl J Med 1998;339: 1044-1053.

112 Olanow CW, Tatton WG: Etiology and pathogenesis of Parkinson's disease. Annu Rev Neurosci 1999;22:123-144.

$\checkmark 113$ Polymeropoulos MH, Lavedan C, Leroy E, Ide SE, Dehejia A, Dutra A, Pike B, Root H, Rubenstein J, Boyer R, Stenroos ES, Chandrasekharappa S, Athanassiadou A, Papapetropoulos T, Johnson WG, Lazzarini AM, Duvoisin RC, Di Iorio G, Golbe LI, Nussbaum RL: Mutation in the alpha-synuclein gene identified in families with Parkinson's disease. Science 1997;276:2045-2047.
114 Kitada T, Asakawa S, Hattori N, Matsumine H, Yamamura Y, Minoshima S, Yokochi M, Mizuno Y, Shimizu N: Mutations in the parkin gene cause autosomal recessive juvenile parkinsonism. Nature 1998;392:605-608.

115 Leroy E, Boyer R, Auburger G, Leube B, Ulm G, Mezey E, Harta G, Brownstein MJ, Jonnalagada S, Chernova T, Dehejia A, Lavedan C, Gasser T, Steinbach PJ, Wilkinson KD, Polymeropoulos MH: The ubiquitin pathway in Parkinson's disease. Nature 1998;395: 451-452.

116 Bonifati V, Rizzu P, van Baron MJ, Schaap O, Breedveld GJ, Krieger E, Dekker MCJ, Squitieri F, Ibanez P, Joosse M, van Dongen JW, Vanacore N, van Swieten JC, Brice A, Meco G, van Duijn CM, Heutink P: Mutations in the $D J-1$ gene associated with autosomal recessive early-onset Parkinsonism. Science 2003;299:256-259.

117 Le W-D, Xu P, Jankovic J, Jiang H, Appel $\mathrm{SH}$, Smith RG, Vassilatis DK: Mutations in NR4A2 associated with familial Parkinson disease. Nat Genet 2003;33:85-89.

118 Scott WK, Nance MA, Watts RL, Hubble JP, Koller WC, Lyons K, Pahwa R, Stern MB, Colcher A, Hiner BC, Jankovic J, Ondo WG, Allen FH Jr, Goetz CG, Small GW, Masterman D, Mastaglia F, Laing NG, Stajich JM, Slotterbeck B, Booze MW, Ribble RC, Rampersaud E, West SG, Gibson RA, Middleton LT, Roses AD, Haines JL, Scott BL, Vance JM, Pericak-Vance MA: Complete genomic screen in Parkinson disease: Evidence for multiple genes. JAMA 2001;286:2239-2244.

119 Valente EM, Bentivoglio AR, Dixon PH, Ferraris A, Ialongo T, Frontali M, Albanese A, Wood NW: Localization of a novel locus for autosomal recessive early-onset Parkinsonism, PARK6, on human chromosome 1p35p36. Am J Hum Genet 2001;68:895-900.

120 Shimura H, Schlossmacher MG, Hattori N, Frosch MP, Trockenbacher A, Schneider R, Mizuno Y, Kosik KS, Selkoe DJ: Ubiquitination of a new form of $\alpha$-synuclein by Parkin from human brain: Implications for Parkinson's disease. Science 2001;293:263-269.

121 Choi P, Golts N, Snyder H, Chong M, Petrucelli L, Hardy J, Sparkman D, Cochran E, Lee JM, Wolozin B: Co-association of parkin and alpha-synuclein. Neuroreport 2001;12:2839_ 2843.

122 Miller DW, Ahmad R, Hague S, Baptista MJ, Canet-Aviles R, McLendon C, Carter DM, Zhu PP, Stadler J, Chandran J, Klinefelter GR, Blackstone C, Cookson MR: L166P mutant DJ-1, causative for recessive Parkinson's disease, is degraded through the ubiquitinproteasome system. J Biol Chem 2003;278: 36588-36595.

123 Lucking CB, Durr A, Bonifati V, Vaughan J, De Michele G, Gasser T, Harhangi BS, Meco G, Denefle P, Wood NW, Agid Y, Brice A: Association between early-onset Parkinson's disease and mutations in the parkin gene. French Parkinson's Disease Genetics Study Group. N Engl J Med 2000;342:1560-1567.
124 Jeon BS, Kim JM, Lee DS, Hattori N, Mizuno Y: An apparently sporadic case with parkin gene mutation in a Korean woman. Arch Neurol 2001;58:988-989.

125 Peng R, Gou Y, Yuan Q, Li T, Latsoudis H, Yuan G, Luo D, Liu X, Collier DA: Mutation screening and association analysis of the parkin gene in Parkinson's disease patients from South-West China. Eur Neurol 2003;49:8589.

126 Oliveira SA, Scott WK, Martin ER, Nance MA, Watts RL, Hubble JP, Koller WC, Pahwa R, Stern MB, Hiner BC, Ondo WG, Allen FH Jr, Scott BL, Goetz CG, Small GW, Mastaglia F, Stajich JM, Zhang F, Booze MW, Winn MP, Middleton LT, Haines JL, Pericak-Vance MA, Vance JM: Parkin mutations and susceptibility alleles in late-onset Parkinson's disease. Ann Neurol 2003;53:624-629.

127 Mori H, Kondo T, Yokochi M, Matsumine H, Nakagawa-Hattori Y, Miyake T, Suda K, Mizuno Y: Pathologic and biochemical studies of juvenile parkinsonism linked to chromosome 6q. Neurology 1998;51:890-892.

128 Morett E, Bork P: A novel transactivation domain in parkin. Trends Biochem Sci 1999; 24:229-231.

129 Moynihan, TP, Ardley HC, Nuber U, Rose SA, Jones PF, Scheffner M, Markham AF, Robinson PA: RING finger and IBR motifs characterize the interaction domains of HHARI and H7-AP1 with the ubiquitin-conjugating enzymes $\mathrm{UbcH} 7$ and $\mathrm{UbcH} 8$. J Biol Chem 1999;274:30963-30967.

130 Imai Y, Soda M, Takahashi R: Parkin suppresses protein stress-induced cell death through its E3 ubiquitin-protein ligase activity. J Biol Chem 2000;275:35661-35664.

131 Zhang Y, Gao J, Chung KKK, Huang H, Dawson VL, Dawson TM: Parkin functions as an E2-dependent ubiquitin-protein ligase and promotes the degradation of the synaptic vesicle-associated protein, CDCrel-1. Proc Natl Acad Sci USA 2000;97:13354-13359.

132 Imai Y, Soda M, Inoue H, Hattori N, Mizuno Y, Takahashi R: An unfolded putative transmembrane polypeptide, which can lead to endoplasmic reticulum stress, is a substrate for Parkin. Cell 2001;105:891-902.

133 Staropoli JF, McDermott C, Martinat C, Schulman B, Demireva E, Abeliovich A: Parkin is a component of an SCF-like ubiquitin ligase complex and protects postmitotic neurons from kainite excitotoxicity. Neuron 2003;37:735-749.

134 Ren Y, Zhao J, Feng J: Parkin binds $\alpha / \beta$ tubulin and increases their ubiquitination and degradation. J Neurosci 2003;23:3316-3324.

135 Corti O, Hampe C, Koutnikova H, Darios F, Jacquier S, Prigent A, Robinson J-C, Pradier L, Ruberg M, Mirande M, et al: The p38 subunit of the aminoacyl-tRNA synthase complex is a Parkin substrate: Linking protein biosynthesis and neurodegeneration. Hum Mol Genet 2003;12:1427-1437. 
136 Choi P, Snyder H, Petrucelli L, Theisler C, Chong M, Zhang Y, Lim K, Chung KK, Kehoe K, D'Adamio L, Lee JM, Cochran E, Bowser R, Dawson TM, Wolozin B: SEPT5_v2 is a parkin-binding protein. Brain Res Mol Brain Res 2003;117:179-189.

137 Huynh DP, Scoles DR, Nguyen D, Pulst SM: The autosomal recessive juvenile Parkinson disease gene product, parkin, interacts with and ubiquitinates synaptotagmin XI. Hum Mol Genet 2003;12:2587-2597.

138 Spillantini MG, Schmidt G, Lee VMY, Trojanowski JQ, Jakes M, Goedert M: Alpha-synuclein in Lewy bodies. Nature 1997;388:839_ 840 .

139 Wakabayashi K, Engelender S, Yoshimoto M, Tsuji S, Ross CA, Takahashi H: Synphilin-1 is present in Lewy bodies in Parkinson's disease. Ann Neurol 2000;47:521-523.

140 Lee HJ, Lee SJ: Characterization of cytoplasmic alpha-synuclein aggregates. Fibril formation is tightly linked to the inclusion-forming process in cells. J Biol Chem 2002;277: 48976-48983.

-141 Petrucelli L, O’Farrell C, Lochhart PJ, Baptista M, Kehoe K, Vink L, Choi P, Wolozin B, Farrer M, Hardy J, Cookson MR: Parkin protects the against the toxicity associated with mutant $\alpha$-synuclein: Proteasome dysfunction selectively affects catecholaminergic neurons. Neuron 2002;36:1007-1019.

142 Yang Y, Nishimura I, Imai Y, Takahashi R, Lu B: Parkin suppresses dopaminergic neuron-selective neurotoxicity induced by Pael-R in Drosophila. Neuron 2003;37:911-924.

-143 Torfaris GK, Razzaq A, Ghetti B, Lilley KS, Spillantini MG: Ubiquitination of $\alpha$-synuclein in Lewy bodies is a pathological event not associated with impairment of proteasome function. J Biol Chem 2003;278: 44405-44411.

$\checkmark 144$ Ito T, Niwa J-i, Hishikawa N, Ishigaki S, Doyu M, Sobue G: Dorfin localizes to Lewy bodies and ubiquitylates synphilin-1. J Biol Chem 2003;278:29106-29114.

- 145 Nagano Y, Yamashita H, Takahashi T, Kishida S, Nakamura T, Iseki E, Hattori N, Mizuno Y, Kikuchi A, Matsumoto M: Siah-1 facilitates ubiquitination and degradation of synphilin-1. J Biol Chem 2003;278:51504-14.

$\checkmark 146$ Liu Y, Fallon L, Lashuel HA, Liu Z, Lansbury PT Jr: The UCH-L1 gene encodes two oppos-
ing enzymatic activities that affect alphasynuclein degradation and Parkinson's disease susceptibility. Cell 2002;111:209-218.

147 Murayama S, Mori H, Ihara Y, Bouldin TW, Suzuki K, Tomonaga M: Immunocytochemical and ultrastructural studies of lower motor neurons in amyotrophic lateral sclerosis. Ann Neurol 1990;27:137-148.

148 Schiffer D, Autilio-Gambetti L, Chio A, Gambetti P, Giordana MT, Gullotta F, Migheli A, Vigliani MC: Ubiquitin in motor neuron disease: Study at the light and electron microscope. J Neuropathol Exp Neurol 1991; 50:463-473.
149 Hishikawa N, Niwa J, Doyu M, Ito T, Ishigaki S, Hashizuma Y, Sobue G: Dorfin localizes to the ubiquitylated inclusions in Parkinson's disease, dementia with lewy bodies, multiple system atrophy, and amyotrophic lateral sclerosis. Am J Pathol 2003;163:609-619.

150 Rosen DR, Siddique T, Patterson D, Figlewicz DA, Sapp P, Hentati A, Donaldson D, Goto J, O'Regan JP, Deng HX, et al: Mutations in $\mathrm{Cu} / \mathrm{Zn}$ superoxide dismutase gene are associated with familial amyotrophic lateral sclerosis. Nature 1993;362:59-62.

151 Valentine JS, Hart PJ: Misfolded CuZnSOD and amyotrophic lateral sclerosis. Proc Natl Acad Sci USA 2003;100:3617-3622.

152 Menzies FM, Cookson MR, Taylor RW, Turnbull DM, Chrzanowska-Lightowlers ZM, Dong L, Figlewicz DA, Shaw PJ: Mitochondrial dysfunction in a cell culture model of familial amyotrophic lateral sclerosis. Brain 2002;125:1522-1533.

153 Beretta S, Sala G, Mattavelli L, Ceresa C, Casciati A, Ferri A, Carri MT, Ferrarese C: Mitochondrial dysfunction due to mutant copper/zinc superoxide dismutase associated with amyotrophic lateral sclerosis is reversed by $\mathrm{N}$-acetylcysteine. Neurobiol Dis 2003;13: 213-221

154 Dupuis L, Di Scala F, Rene F, De Tapia M, Oudart H, Pradat PF, Meininger V, Loeffler JP: Up-regulation of mitochondrial uncoupling protein 3 reveals an early muscular metabolic defect in amyotrophic lateral sclerosis. FASEB J 2003;17:2091-2093.

155 Urushitani M, Kurisu J, Tsukita K, Takahashi R: Proteasomal inhibition by misfolded mutant superoxide dismutase 1 induces selective motor neuron death in familial amyotrophic lateral sclerosis. J Neurochem 2002; 83:1030-1042.

156 La Spada AR, Taylor JP: Polyglutamines placed in context. Neuron 2003;38:681-684.

157 Michalik A, Van Broeckhoven C: Pathogenesis of polyglutamine disorders: Aggregation revisited. Hum Mol Genet 2003;12:R173R186.

158 Tsai YC, Fishman PS, Thakor NV, Oyler GA: Parkin facilitates the elimination of expanded polyglutamine proteins and leads to preservation of proteasome function. J Biol Chem 2003;278:22044-22055.

159 The Huntington's Disease Collaborative Research Group: A novel gene containing a trinucleotide repeat that is expanded and unstable on Huntington's disease chromosomes. Cell 1993;72:971-983.

160 Davies SW, Turmaine M, Cozens BA, DiFiglia M, Sharp AH, Ross CA, Scherzinger E, Wanker EE, Mangiarini L, Bates GP: Formation of neuronal intranuclear inclusions underlies the neurological dysfunction in mice transgenic for the HD mutation. Cell 1997; 90:537-548.

161 DiFiglia M, Sapp E, Chase KO, Davies SW, Bates GP, Vonsattel JP, Aronin N: Aggregation of huntingtin in neuronal intranuclear inclusions and dystrophic neurites in brain. Science 1997;277:1990-1993.
162 Kalchman MA, Graham RK, Xia G, Koide HB, Hodgson JG, Graham KC, Goldberg YP Gietz RD, Pickart CM, Hayden MR: Huntingtin is ubiquitinated and interacts with a specific ubiquitin-conjugating enzyme. J Biol Chem 1996;271:19385-19394.

163 Harjes P, Wanker EE: The hunt for huntingtin function: Interaction partners tell many different stories. Trends Biochem Sci 2003; 28:425-433.

164 Lee S-J, Choi J-Y, Sung Y-M, Park H, Rhim $\mathrm{H}$, Kang S: E3 ligase activity of RING finger proteins that interact with Hip-2, a human ubiquitin-conjugating enzyme. FEBS Lett 2001;503:61-64.

165 Orr HT, Chung MY, Banfi S, Kwiatkowski TJ Jr, Servadio A, Beaudet AL, McCall AE Duvick LA, Ranum LP, Zoghbi HY: Expansion of an unstable trinucleotide CAG repeat in spinocerebellar ataxia type 1 . Nat Genet 1993;4:221-226.

166 Skinner PJ, Koshy BT, Cummings CJ, Klement IA, Helin K, Servadio A, Zoghbi HY, Orr HT: Ataxin-1 with an expanded glutamine tract alters nuclear matrix-associated structures. Nature 1997;389:971-974.

167 Cummings CJ, Reinstein E, Sun Y, Antalffy B, Jiang Y-h, Ciechanover A, Orr HT, Beaudet AL, Zoghbi HY: Mutation of the E6-AP ubiquitin ligase reduces nuclear inclusion frequency while accelerating polyglutamine-induced pathology in SCA1 mice. Cell 1999;24: 879-892.

168 Koshy BT, Zoghbi HY: The CAG/polyglutamine tract diseases: Gene products and molecular pathogenesis. Brain Pathol 1997;7: 927-942.

169 Quigley CA, De Bellis A, Marschke KB, elAwady MK, Wilson EM, French FS: Androgen receptor defects: historical, clinical, and molecular perspectives. Endocr Rev 1995;16: 271-321.

170 McKenna NJ, Lanz RB, O’Malley BW: Nuclear receptor coregulators: Cellular and molecular biology. Endocr Rev 1999;20:321344.

171 Lonard DM, Nawaz Z, Smith CL, O'Malley $\mathrm{BW}$ : The $26 \mathrm{~S}$ proteasome is required for estrogen receptor-alpha and coactivator turnover and for efficient estrogen receptor-alpha transactivation. Mol Cell 2000;5:939-948.

172 Tschugguel W, Dietrich W, Zhegu Z, Stonek F, Kolbus A, Huber JC: Differential regulation of proteasome-dependent estrogen receptor alpha and beta turnover in cultured human uterine artery endothelial cells. J Clin Endocrinol Metab 2003;88:2281-2287.

173 Li M, Miwa S, Kobayashi Y, Merry DE, Yamamoto M, Tanaka F, Doyu M, Hashizume Y, Fischbeck KH, Sobue G: Nuclear inclusions of the androgen receptor protein in spinal and bulbar muscular atrophy. Ann Neurol 1998;44:249-254.

174 Abel A, Walcott J, Woods J, Duda J, Merry DE: Expression of expanded repeat androgen receptor produces neurologic disease in transgenic mice. Hum Mol Genet 2001;10:107116 
175 Katsuno M, Adachi H, Inukai A, Sobue G: Transgenic mouse models of spinal and bulbar muscular atrophy (SBMA). Cytogenet Genome Res 2003;100:243-251.

$\checkmark 176$ Moilanen A-M, Poukka H, Karvonen U, Hakli M, Janne OA, Palvimo JJ: Identification of a novel RING finger protein as a coregulator in steroid receptor-mediated gene transcription. Mol Cell Biol 1998;18:51285139.

- 177 Beitel LK, Elhaji YA, Lumbroso R, Wing SS, Panet-Raymond V, Gottlieb B, Pinsky L, Trifiro MA: Cloning and characterisation of an antrogen receptor $\mathrm{N}$-terminal-interacting protein with ubiquitin-protein ligase activity. J Mol Endocrinol 2002;29:41-60.

178 Kang H-Y, Yeh S, Fujimoto N, Chang C: Cloning and characterization of human prostate coactivator ARA54, a novel protein that associates with the androgen receptor. J Biol Chem 1999;274:8570-8576.

179 Starita LM, Parvin JD: The multiple nuclear functions of BRCA1: Transcription, ubiquitination and DNA repair. Curr Opin Cell Biol 2003; 15:345-350.

180 Nawaz Z, Lonard DM, Smith CL, Lev-Lehman E, Tsai SY, Tsai MJ, O’Malley BW: The Angelman syndrome-associated protein, E6$\mathrm{AP}$, is a coactivator for the nuclear hormone receptor superfamily. Mol Cell Biol 1999;19: 1182-1189.

-181 Li SH, McInnis MG, Margolis RL, Antonarakis SE, Ross CA: Novel triplet repeat containing genes in human brain: Cloning, expression, and length polymorphisms. Genomics 1993; 16:572-579.

$>182$ Koide R, Ikeuchi T, Onodera O, Tanaka H, Igarashi S, Endo K, Takahashi H, Kondo R, Ishikawa A, Hayashi T, Saito M, Tomoda A, Miike T, Naito H, Ikuta F, Tsuji S: Unstable expansion of CAG repeat in hereditary dentatorubral-pallidoluysian atrophy (DRPLA) Nat Genet 1994;6:9-13.

183 Deka R, Miki T, Yin SJ, McGarvey ST, Shriver MD, Bunker CH, Raskin S, Hundrieser J, Ferrell RE, Chakraborty R: Normal CAG repeat variation at the DRPLA locus in world populations. Am J Hum Genet 1995; 57:508-511.

184 Zhang S, Xu L, Lee J, Xu T: Drosophila atrophin homolog functions as a transcriptional corepressor in multiple developmental processes. Cell 2002;108:45-56.

$\checkmark 185$ Erkner A, Roure A, Charroux B, Delaage M, Holway N, Core N, Vola C, Angelats C, Pages F, Fasano L, Kerridge S: Grunge, related to human Atrophin-like proteins, has multiple functions in Drosophila development. Development 2002;129:1119-1129.

186 Yazawa I, Nakase H, Kurisaki H: Abnormal dentatorubral-pallidoluysian atrophy (DRPLA) protein complex is pathologically ubiquitinated in DRPLA brains. Biochem Biophys Res Commun 1999;260:133-138.
187 Wood JD, Yuan J, Margolis RL, Colomer V, Duan K, Kushi J, Kaminsky Z, Kleiderlein JJ $\mathrm{Jr}$, Sharp AH, Ross CA: Atrophin-1, the DRPLA gene product, interacts with two families of WW domain-containing proteins. Mol Cell Neurosci 1998;11:149-160.

188 Ding Q, Lewis JJ, Strum KM, Dimayuga E, Bruce-Keller AJ, Dunn JC, Keller JN: Polyglutamine expansion, protein aggregation, proteasome activity, and neural survival. J Biol Chem 2002;277:13935-13942.

189 Hashizume R, Fukuda M, Maeda I, Nishikawa H, Oyake D, Yabuki Y, Ogata H, Ohta T: The RING heterodimer BRCA1-BARD1 is a ubiquitin ligase inactivated by a breast cancer-derived mutation. J Biol Chem 2001;276: 14537-14540.

190 Badciong JC, Haas AL: MdmX is a RING finger ubiquitin ligase capable of synergistically enhancing Mdm2 ubiquitination. J Biol Chem 2002;277:49668-49675.

191 Xia Y, Pao GM, Chen HW, Verma IM, Hunter T: Enhancement of BRCA1 E3 ubiquitin ligase activity through direct interaction with the BARD1 protein. J Biol Chem 2003;278: 5255-5263.

192 Courbard J-R, Fiore F, Adelaide J, Borg J-P, Birnbaum D, Ollendorf V: Interaction between two ubiquitin-protein isopeptide ligases of different classes, CBLC and AIP4/ ITCH. J Biol Chem 2002;277:45267-45275.

193 Prusiner SB: Neurodegenerative diseases and prions. N Engl J Med 2001;344:1516-1526.

194 Dimcheff DE, Portis JL, Caughey B: Prion proteins meet quality control. Trends Cell Biol 2003;13:337-340.

195 Ma J, Lindquist S: Wild-type PrP and a mutant associated with prion disease are subject to retrograde transport and proteasome degradation. Proc Natl Acad Sci USA 2001;98: 14955-15960.

196 Phan LK, Lin F, LeDuc CA, Chung WK, Leibel RL: The mouse mahoganoid coat color mutation disrupts a novel C3HC4 RING domain protein. J Clin Invest 2002;110:14491459.

197 He L, Lu X-Y, Jolly AF, Eldridge AG, Watson SJ, Jackson PK, Barsh GS, Gunn TM: Spongiform degeneration in mahoganiod mutant mice. Science 2003;299:710-712.

198 Ganesh S, Delgado-Escueta AV, Sakamoto T, Avila MR, Machado-Salas J, Hoshii Y, Akagi T, Gomi H, Suzuki T, Amano K, Agarwala KL, Hasegawa Y, Bai DS, Ishihara T, Hashikawa T, Itohara S, Cornford EM, Niki H, Yamakawa K: Targeted disruption of the Epm2a gene causes formation of Lafora inclusion bodies, neurodegeneration, ataxia, myoclonus epilepsy and impaired behavioral response in mice. Hum Mol Genet 2002;11: 1251-1262.
199 Ganesh S, Delgado-Escueta AV, Suzuki T, Francheschetti S, Riggio C, Avanzini G, Rabinowicz A, Bohlega S, Bailey J, Alonso ME, Rasmussen A, Thomson AE, Ochoa A, Prado AJ, Medina MT, Yamakawa K: Genotypephenotype correlations for EPM2A mutations in Lafora's progressive myoclonus epilepsy: Exon 1 mutations associate with an early-onset cognitive deficit subphenotype. Hum Mol Genet 2002;11:1263-1271.

200 Chan EM, Young EJ, Ianzano L, Munteanu I, Zhao X, Christopoulos CC, Avanzini G, Elia M, Ackerley CA, Jovic NJ, Bohlega S, Andermann E, Rouleau GA, Delgado-Escueta AV, Minassian BA, Scherer SW: Mutations in NHLRC1 cause progressive myoclonus epilepsy. Nat Genet 2003;35:125-127.

201 Minassian BA: Progressive myoclonus epilepsy with polyglucosan bodies: Lafora disease. Adv Neurol 2002;89:199-210.

202 Minassian BA, Lee JR, Herbrick JA, Huizenga J, Soder S, Mungall AJ, Dunham I, Gardner R, Fong CY, Carpenter S, Jardim L, Satishchandra P, Andermann E, Snead OC 3rd, Lopes-Cendes I, Tsui LC, Delgado-Escueta AV, Rouleau GA, Scherer SW: Mutations in a gene encoding a novel protein tyrosine phosphatase cause progressive myoclonus epilepsy. Nat Genet 1998;20:171-174.

203 Wang G-h, Sawai N, Kotliarova S, Kanazawa I, Nukina N: Ataxin-3, the $M J D 1$, gene product, interacts with the two human homologs of yeast DNA repair protein RAD23, HHR23A and HHR23B. Hum Mol Genet 2000;9:1795-1803.

204 Burnett B, Li F, Pittman RM: The polyglutamine neurodegenerative protein ataxin-3 binds polyubiquitylated proteins and has ubiquitin protease activity. Hum Mol Genet 2003; 12:3195-3205.

205 Matilla A, Gorbea C, Einum DD, Townsend J, Michalik A, van Broeckhoven C, Jensen CC, Murphy KJ, Ptacek LJ, Fu Y-C: Association of ataxin-7 with the proteasome subunit S4 of the 19S regulatory complex. Hum Mol Genet 2001;10:2821-2831

206 Terashima T, Kawai H, Fujitani M, Maeda K, Yasuda H: SUMO-1 co-localized with mutant atrophin-1 with expanded polyglutamines accelerates intranuclear aggregation and cell death. Neuroreport 2002;13:23592364.

207 Kuusisto E, Salminen A, Alafuzoff I: Ubiquitin-binding protein p62 is present in neuronal and glial inclusions in human tauopathies and synucleinopathies. Neuroreport 2001;12:2085-2090.

208 Kuusisto E, Salminen A, Alafuzoff I: Early accumulation of $\mathrm{p} 62$ in neurofibrillary tangles in Alzheimer's disease: Possible role in tangle formation. Neuropathol Appl Neurobiol 2002;28:228-237.

209 Arai T, Nonaka T, Hasegawa M, Akiyama H, Yoshida M, Hashizume Y, Tsuchiya K, Oda $\mathrm{T}$, Ikeda K: Neuronal and glial inclusions in frontotemporal dementia with or without motor neuron disease are immunopositive for p62. Neurosci Lett 2003;342:41-44. 
210 Favit A, Grimaldi M, Alkon DL: Prevention of beta-amyloid neurotoxicity by blockade of the ubiquitin-proteasome proteolytic pathway. J Neurochem 2000;75:1258-1263.

-211 Gregori L, Fuchs C, Figueiredo-Pereira ME, Van Nostrand WE, Goldgaber D: Amyloid beta-protein inhibits ubiquitin-dependent protein degradation in vitro. $\mathrm{J}$ Biol Chem 1995;270:19702-19708.

212 Gregori L, Hainfeld JF, Simon MN, Goldgaber D: Binding of amyloid beta protein to the 20 S proteasome. J Biol Chem 1997;272:5862.
213 David DC, Layfield R, Serpell L, Narain Y Goedert M, Spillantini MG: Proteasomal degradation of tau protein. J Neurochem 2002;83:176-185.

214 Tofaris GK, Layfield R, Spillantini MG: Alpha-synuclein metabolism and aggregation is linked to ubiquitin-independent degradation by the proteasome. FEBS Lett 2001;509:2226.

215 Lam YA, Pickart CM, Alban A, Landon M, Jamieson C, Ramage R, Mayer RJ, Layfield $\mathrm{R}$ : Inhibition of the ubiquitin-proteasome system in Alzheimer's disease. Proc Natl Acad Sci USA 2000;97:9902-9906.

$\checkmark 216$ Layfield R: Does an inhibition of the ubiquitin/26S proteasome pathway of protein degradation underlie the pathogenesis of non-familial Alzheimer's disease? Med Hypotheses 2001;56:395-399.
217 Lindsten K, de Vrij FM, Verhoef LG, Fischer DF, van Leeuwen FW, Hol EM, Masucci MG, Dantuma NP: Mutant ubiquitin found in neurodegenerative disorders is a ubiquitin fusion degradation substrate that blocks proteasomal degradation. J Cell Biol 2002;157: 417-427.

218 van Leeuwen FW, Gerez L, Benne R, Hol EM: +1 Proteins and aging. Int $\mathrm{J}$ Biochem Cell Biol 2002;34:1502-1505.

$\checkmark 219$ Hope AD, de Silva R, Fischer DF, Hol EM, van Leeuwen FW, Lees AJ: Alzheimer's associated variant ubiquitin causes inhibition of the $26 \mathrm{~S}$ proteasome and chaperone expression. J Neurochem 2003;86:394-404. 